University of Louisville

ThinkIR: The University of Louisville's Institutional Repository

\title{
A spatial analysis of the relationship between violent neighborhood crime rates and alternative gentrification indicators in Louisville, KY (2010-2016).
}

George A. Noonan

University of Louisville

Follow this and additional works at: https://ir.library.louisville.edu/etd

Part of the Geographic Information Sciences Commons

\section{Recommended Citation}

Noonan, George A., "A spatial analysis of the relationship between violent neighborhood crime rates and alternative gentrification indicators in Louisville, KY (2010-2016)." (2017). Electronic Theses and

Dissertations. Paper 2644.

https://doi.org/10.18297/etd/2644

This Master's Thesis is brought to you for free and open access by ThinkIR: The University of Louisville's Institutional Repository. It has been accepted for inclusion in Electronic Theses and Dissertations by an authorized administrator of ThinkIR: The University of Louisville's Institutional Repository. This title appears here courtesy of the author, who has retained all other copyrights. For more information, please contact thinkir@louisville.edu. 


\title{
A SPATIAL ANALYSIS OF THE RELATIONSHIP BETWEEN VIOLENT NEIGHBORHOOD CRIME RATES AND ALTERNATIVE GENTRIFICATION INDICATORS IN LOUISVILLE, KY (2010-2016)
}

\section{By}

George A. Noonan

B.S. University of Louisville, 2013

\author{
A Thesis \\ Submitted to the Faculty of the \\ College of Arts and Sciences of the University of Louisville \\ in Partial Fulfillment of the Requirements \\ for the Degree of
}

Master of Arts in Applied Geography

Department of Geography and Geosciences

University of Louisville

Louisville, KY

May 2017 

A SPATIAL ANALYSIS OF THE RELATIONSHIP BETWEEN VIOLENT NEIGHBORHOOD CRIME RATES AND ALTERNATIVE GENTRIFICATION INDICATORS IN LOUISVILLE, KY (2010-2016)

By

George A. Noonan

B.S. University of Louisville, 2015

A Thesis Approved on

April 18, 2017

by the following Thesis Committee:

Thesis or Dissertation Director

Dr. Haifeng Zhang

Second Committee Member Name

Dr. Carol Hanchette

Third Committee Member Name

Dr. Sumei Zhang 


\begin{abstract}
A SPATIAL ANALYSIS OF THE RELATIONSHIP BETWEEN VIOLENT NEIGHBORHOOD CRIME RATES AND ALTERNATIVE GENTRIFICATION INDICATORS IN LOUISVILLE, KY (2010-2016)
\end{abstract}

\author{
George A. Noonan
}

18 April 2017

This study analyzes recent findings analyzing coffee shops as alternative indicators of gentrification and the spatial relationship to violent crime. This thesis seeks to add to this literature by providing additional alternative gentrification indicators such as breweries, distilleries and wineries. The change in number of coffee shops, breweries, distilleries and wineries may impact crime rates and multiyear average incidences of homicide and robbery in the city of Louisville, KY. The first hypothesis states that gentrification decreases multiyear average robberies per census tract from 2010 to 2016 . The second hypothesis states that gentrification decreases multiyear average homicides per census tract from 2010 to 2016. Described by three criminological theories: routine activities theory, social disorganization theory and broken window theory. Multiyear averages for robberies and homicides were spatially analyzed with these alternative gentrification indicators and their change over time. This thesis found that multiyear average robberies have a higher negative relationship with alternative gentrification indicators in census tracts found in lower income neighborhoods. There was no significant relationship between multiyear average homicides and alternative gentrification indicators. 
TABLE OF CONTENTS

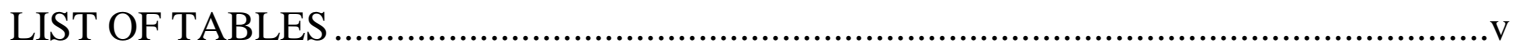

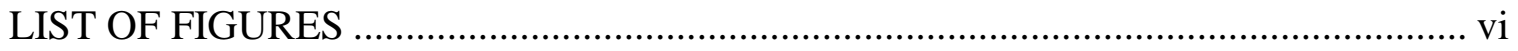

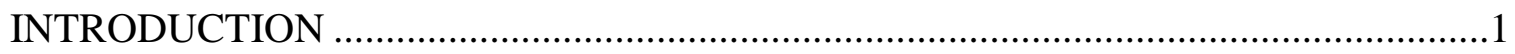

CRIMONOLOGY LITERATURE ....................................................................

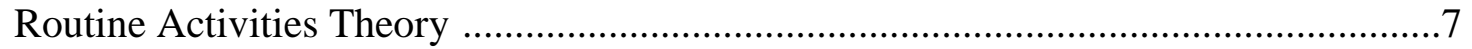

Social Disorganization Theory .......................................................................

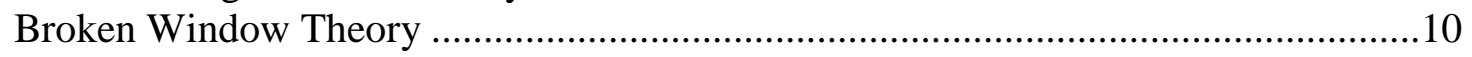

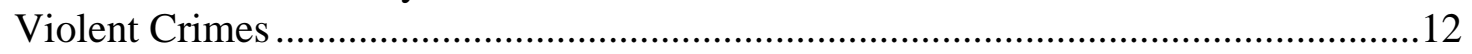

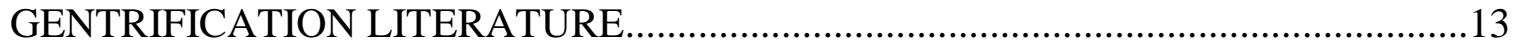

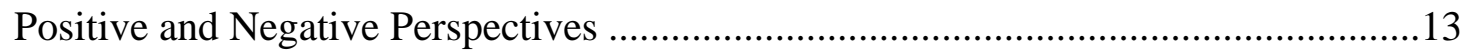

Gentrification: Decrease in Crime .................................................................... 14

Gentrification: Increase in Crime...................................................................... 16

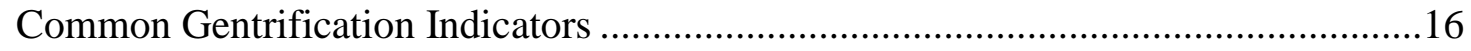

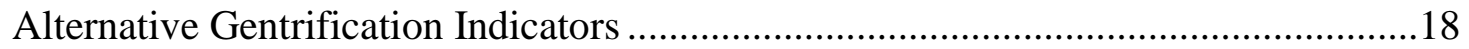

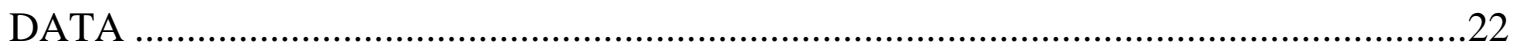

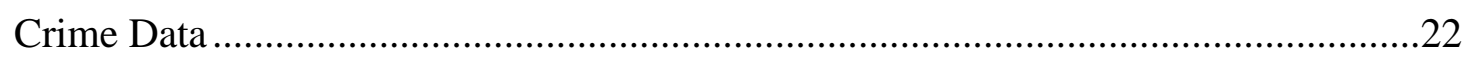

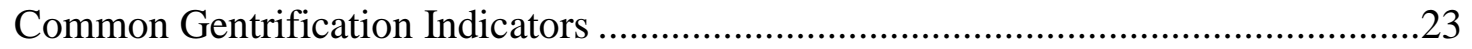

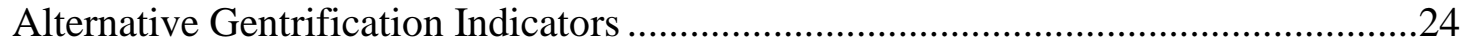

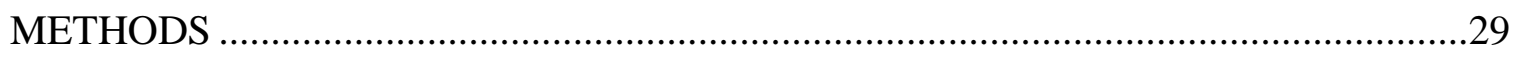

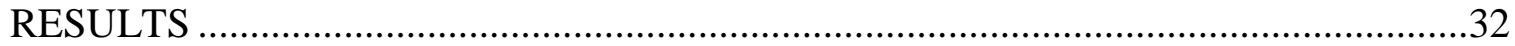

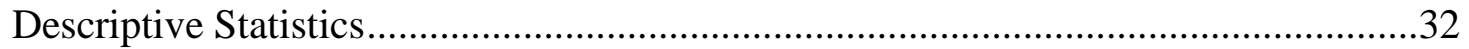

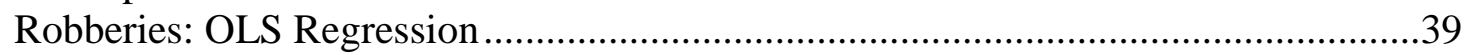

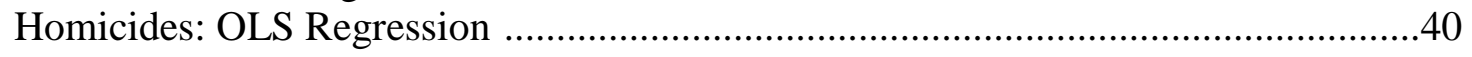

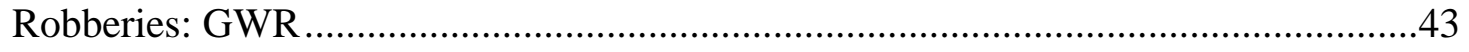

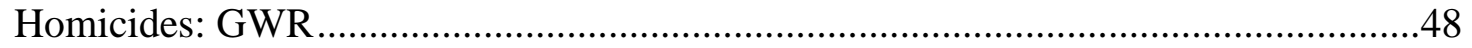

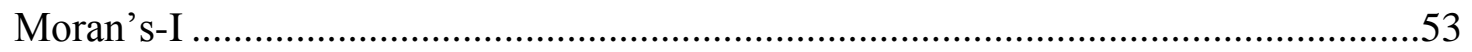

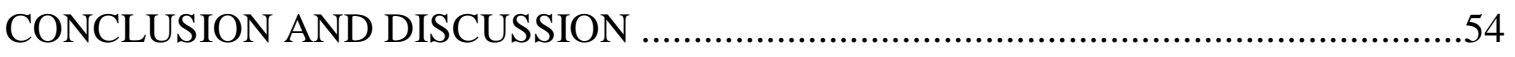

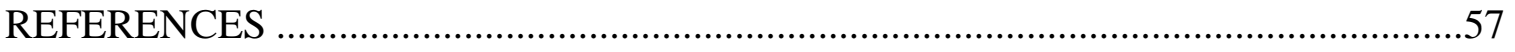

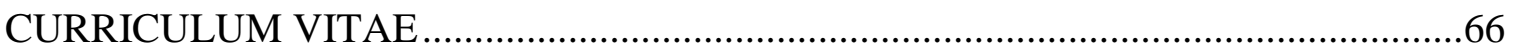




\section{LIST OF TABLES}

$\begin{array}{lll}\text { TABLE } & \text { PAGE }\end{array}$

1. Descriptive statistics of dependent and independent variables .................................33

2. Descriptive statistics for the change between selected LMPD and

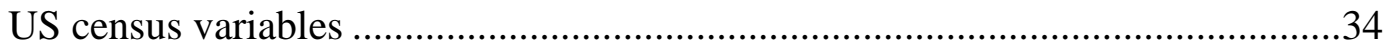

3. Results of OLS regressions analysis for robberies (multiyear average)

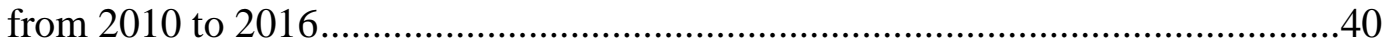

4. Results of OLS regression analysis for homicides (multiyear average)

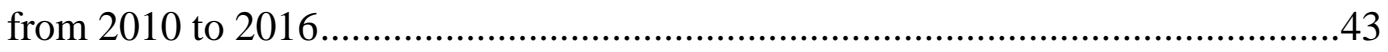

5. Results of GWR analysis for robberies (multiyear average)

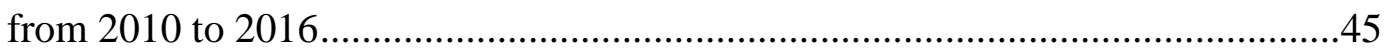

6. Results of GWR analysis for homicides (multiyear average)

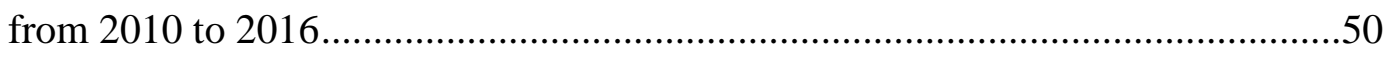

7. Comparison of Moran's-I results for all models ................................................53 


\section{LIST OF FIGURES}

$\begin{array}{lll}\text { TABLE } & \text { PAGE }\end{array}$

1. Census tract boundaries for Louisville, KY; select regional names ...........................6

2. 2010 and 2016 urban amenities used to compute the two independent variables (urban amenity locations and alternative gentrification indicator)........26

3. Choropleth map showing the distribution of urban amenities for

2010 and 2016

4. Alternative gentrification indicators; change in the total count of urban amenities from 2010 to 2016

5. Local coefficients for urban amenities in 2016 and multiyear average robbery rates from 2010 to 2016

6. Local coefficients for alternative gentrification indicator from

2010 to 2016 and multiyear average robbery rates from 2010 to 2016

7. Local coefficients for residential mobility in 2015 and the

multiyear average robbery rate from 2010 to 2016 


\section{INTRODUCTION}

Many neighborhoods across US central cities have rebounded due to recent demographic and economic shifts that have renewed interests in urban living (Ding et al. 2016). This has led to gentrification, the process by which higher income households replace the original lower income households after an inner city neighborhood has been rehabilitated or renovated, ultimately changing the essential character and flavor of that neighborhood (Barton 2014, Kennedy and Leonard 2001). Understanding the relationship between gentrification and crime can lead to policies that decrease violence amongst neighborhoods. Gentrification has been linked to changes in local crime patterns, but the research itself is contradictory (Atkinson 2004).The few empirical tests on the relationship between gentrification and crime have found inconsistent findings (Papachristos et al. 2011). For example, Papachristos et al. (2011) found that gentrification with increased amenities, such as coffee shops, are related to the decline in homicides and robberies in Chicago neighborhoods. Proponents of gentrification widely claim that reductions in neighborhood crime rates are a benefit of gentrification at the neighborhood and even city level (Papachristos et al. 2011). However, other studies have suggested that gentrification can increase crime (Covington and Taylor 1989; Lee 2010; Van Wilsem and De Graff 2006). Gentrification can be described as a process of spatial and social differentiation (Zurkin 1987). The literature on the relationship between gentrification and crime is often prevalent is spatial sciences. 
The process of gentrification often occurs in urban neighborhoods that are highly associated with poverty, unemployment, lack of education, and higher percentage of minorities. The way in which social scientists label or define gentrification is key to understanding the spatial relationship of gentrification and crime. The variables or indicators used to identify gentrification in geography are most often the US Census Bureau tabulated data on population migration, but recent literature has highlighted indicators that are more precise. Papachristos et al. (2011) identified a relationship between gentrification and coffee shops and found that coffee shops are an additional indicator of gentrification as third places that offer amenities. These are areas in which people are allowed to congregate and spend time after a small purchase. Common indicators such as median household income and racial composition are commonly used to determine gentrification as well. However, using alternative indicators based on qualitative research can provide in-depth context to the subject. With this understanding, additional indicators of gentrification were increasingly used in the empirical research. Mathews (2014) studied the relationship between brewpubs and breweries with gentrification. The methods were qualitative.

Other commercial activities that are similar to breweries and brew pubs such as distilleries and wineries would have similar impacts on crime at the neighborhood level. According to the Kentucky Distilling Associations (KDA) (2014), the Kentucky bourbon market has seen distillers invest more than $\$ 400$ million from 2009 to 2014 and expect to spend another $\$ 630$ million from 2015 to 2020 . It is apparent that majority of these new locations are popping up on Main Street. The traditional rural winery-vineyard combination has converged with recent on-going gentrification and urban renewal taking 
place across America (VornDick 2014). These activities are similar to coffee shops as they have seen a recent increase amongst the urban setting, in which cultural and demographic changes are shaping the influence on violent crimes.

The objective of this paper is to investigate the impact of gentrification on spatial and temporal patterns of crime in Louisville Metro - Jefferson County, Kentucky. In particular, this paper will focus on the occurrence of homicide and robbery in gentrified neighborhoods. These establishments may be an indication that gentrification is on the horizon, which should alarm neighborhood and citywide planners to focus on ensuring their ability to adjust to either an increase or decrease in crime. This thesis seeks to understand the relationship between gentrification indicators including number of coffee shops, breweries, distilleries and multiyear averages for homicides and robberies from 2010 through 2016.The two primary research questions are: (1) has gentrification resulted in a decrease in homicide rates from 2010 to 2016, and (2) has gentrification resulted in a decrease in robbery rates from 2010 to 2016 ? To answer the above questions, this thesis identifies relevant literature on gentrification and crime, as well as both quantitative and qualitative findings that connect the importance of coffee shops, breweries, distilleries, and wineries as places that offer high amenities. A thorough literature review is necessary to highlight the interrelationship between gentrification and its effect on crime rates. Fortunately, criminology theories are common in geographic literature and analysis (Zhang and McCord 2014).

The first part of the literature review focuses on three criminology theories: (1) routine activities theory, (2) social disorganization theory, and (3) broken window theory. All three are useful in explaining the potential crime impact on a neighborhood as each 
approach the issue from a different angle (Zhang and McCord 2014).These three theories found in criminology are well known in geographic literature. The inclusion of criminology into this study is beneficial alongside the spatial awareness in geography. The results provide a better understanding of the dispersion or concentration of crime in relation to on-going gentrification. The second part of the literature review discussed how gentrification is related to socioeconomic factors. This part focuses on the positive and negative associations between gentrification and crime. The last section highlights the shortcomings of previous scholars on the subject gentrification and crime. The acquisition and management of various data sources in geographic information systems (GIS) can provide a spatial analysis. Following the literature review is the data section. The data for this thesis is derived from several datasets. These include: (1) crime data from the Louisville Metropolitan Police Department (LMPD), demographic and social characteristics from the US-Census American Community Survey (ACS) 5-Years estimates, land use data from Louisville Jefferson County Information Consortium (LOJIC), and the combination of two business directories (regional and local) for contemporary and temporal locations by address for gentrification indicators from 2010 to 2016. The addition of the Louisville metro restaurant scores was necessary to identify the most recent coffee shops. The two main dependent variables derived will represent (1) urban amenity locations as measured by the contemporary location of a coffee shop, brewery, distillery, and winery; and (2) gentrification as measured by the change in these locations from 2010 to 2016.

The methods are a multiple step empirical analysis. The methods used are GIS based. ESRI's ArcGIS $10.2+$ provides the platform to manage multiple spatial datasets 
for analysis. The methodology used is quantitative and GIS based. It contains the following steps: First, I conducted a descriptive statistical analysis at the census tract level. Secondly, I tested the effect of these alternative gentrification indicators by conducting two OLS regression (longitudinal analysis) models for robberies and homicides from 2010 to 2015. A Moran's-I test was necessary to determine the rate of spatial autocorrelation for the two OLS models. Lastly, a Geographically Weighted Regression (GWR) models was conducted for both dependent variables. The results for homicides and robberies are reviewed and discussed following the methodologies. Understanding the relationship between gentrification and crime is imperative for future policy and city planning. The ultimate goal is to invoke efficient policies that address crime as it relates to the gentrification of neighborhoods, and its relationship to neighborhood crime. The study area for this analysis is shown in figure 1 with regional and neighborhood names. 


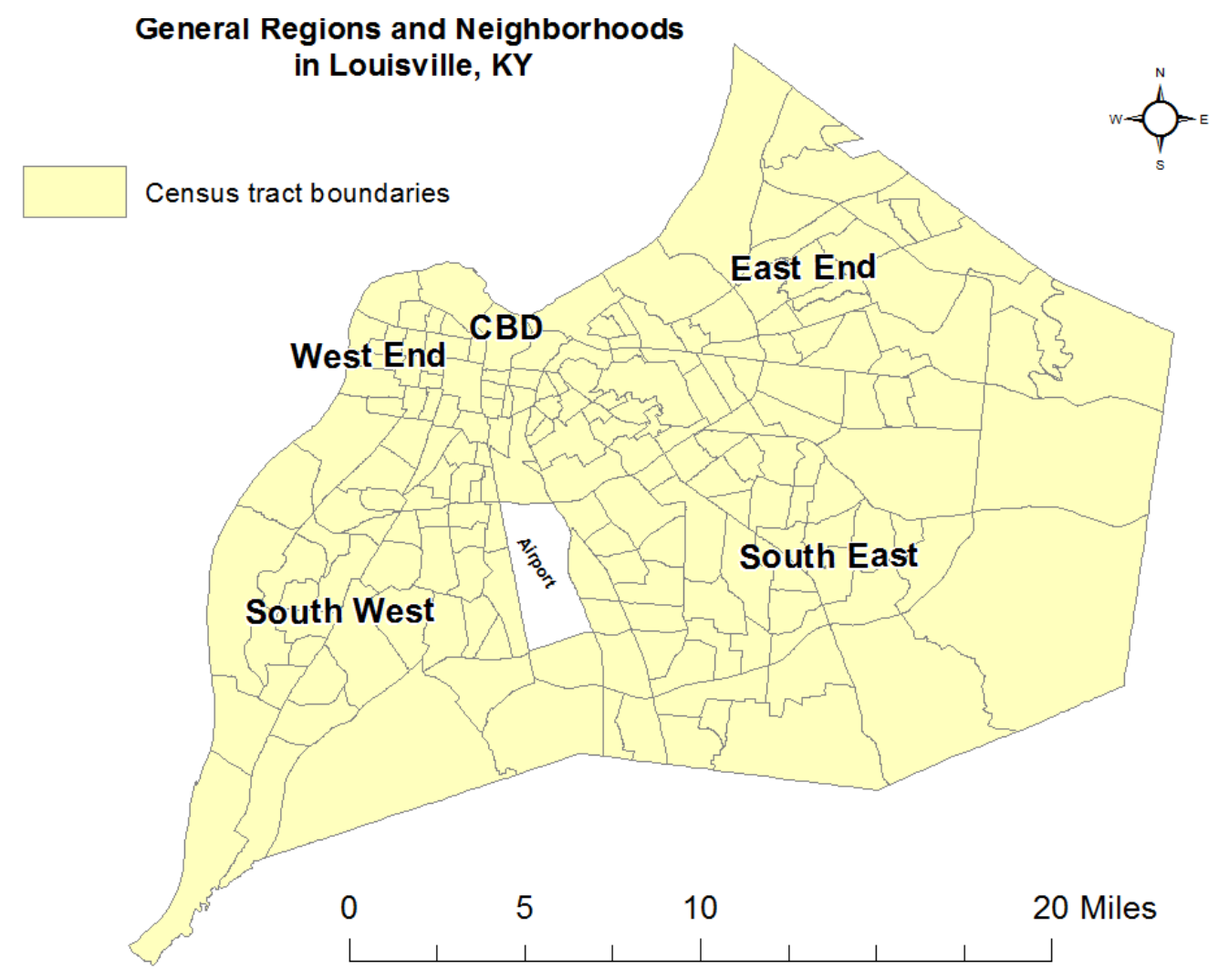

Figure 1. Census tract boundaries for Louisville, KY; select regional names. 


\section{CRIMINOLOGY LITERATURE}

\section{Routine Activities Theory}

It is important that researchers carefully examine existing criminological theories instead of relying on blanket characterizations (Akers 1990). The routine activities theory states that crime is likely to occur when motivated offenders and suitable targets converge in time and space with the absence of capable guardians (Cohen and Felson 1979). Criminal activities are related to the characteristics of the social environment and the behavior patterns of the people who live in the neighborhood or community (Zhang and Peterson 2007). The structure of activities in everyday life influence criminal opportunities and therefore affects the trend in predatory violations (Cohen and Felson 1979). Predatory violations are defined as illegal acts in which someone intentionally takes or damages the person or property of another (Cohen and Felson 1979; Glaser 1971). The process of higher income individuals moving into lower income neighborhoods would affect the daily routine of criminals.

According to the routine activity theory, there are three elements that are related to crime: (1) abundant opportunities, (2) profitable targets, and (3) least risk or lack of surveillance (Anselin at al. 2000; Roncek and Maier, 1991; Sherman et al. 1989). High crime rates occur in neighborhoods with a concentration of motivated criminals with desirable victims and few deterrents (Brehon 2007). This theory suggests an increase in robberies with the addition of affluent patrons and businesses in neighborhoods of poverty. 
The social structure of guardianship (lack of discipline, police presence, etc) in any neighborhood will vary and this will promote different levels of community involvement and wellbeing. Guardianship or the absence thereof, plays an important role in explaining the occurrence of crime (Zhang and McCord 2014). In neighborhoods with higher concentration of crime, there tends to be an increase in police presence. Coffee shops, breweries, distilleries, and wineries offer amenities products and experiences in an urban setting that may alter the occurrence of criminal activities in the area.

\section{Social Disorganization Theory}

Social disorganization theory has experienced a renaissance in recent years (Kubrin and Weitzer 2003). Given increasing deindustrialization of central cities, heightened middle-class mobility, growing segregation and isolation of the poor, and the growth of immigrant populations in most American cities, the theory's relevance is perhaps even stronger today than when it was first proposed many decades ago (Kubrin and Weizer 2003). As neighborhoods stabilize, coffee shops (like other social institutions) might provide additional "eyes on the streets" to monitor public behavior (Papachristos et al. 2011). Crime, therefore, would eventually decrease as neighborhood structural conditions stabilize, thereby improving the overall safety of neighborhood residents (Papachristos et al. 2011). This decrease in crime would facilitate more urban renewal if they focus on the direct impacts. According to the literature, it is unclear if disorder and crime are distinct concepts or if they are at opposite ends of the same continuum (Meinen 2014). Neighborhoods with the highest median household incomes are assumed to be on the higher end of this continuum, and vice versa. 
Social disorganization suggests a negative association between gentrification and crime as there is a decrease in crime due to a prevalence of people in the area. This is similar to the routine activity theory, in which guardianship dictates criminal activity. Social disorganization predicts high crime rates in neighborhoods with high poverty rates, high levels of renters, single parent families, and ethnic heterogeneity (Brehon 2007).Ethnic heterogeneity is rare in Louisville, as it is extremely segregated. Ethnic heterogeneity does occur in some South, South West, and Western neighborhoods. This theory explains why some communities have higher crime rates than others, rather than why some individual people commit crime and others do not (Miller, Schreck, and Tewksbury 2006). Proponents for gentrification would point towards social disorganization as enabling retrofitting and the refurbishment of inner city neighborhoods. In terms of direct impact, social disorganization theory is sufficient for explaining the negative relationship between gentrification and crime. The indirect impact on crime through displacement of original low-income residents after a neighborhood is gentrified would assume a positive relationship between violent crimes and new commercial activities that are associated with gentrification.

Socially and economically disadvantaged residents are often displaced during the process of gentrification. Unfortunately, any stability that results from gentrification is geared towards the gentrifiers themselves. Essentially, gentrifiers desire disorganized areas in order to reorganize them while making them exclusive. Low-income residents are assumed to be disorganized as they often lack the additional income to help upkeep the built environment. Low-income residents are assumed to lack financial freedom (Sampson and Groves 1989). This lack of financial freedom is strenuous and is often 
clustered in areas that have low educational attainment and high poverty rates. Social disorganization theory is adequate in describing gentrification as a process that helps regain and strengthen order in urban areas.

\section{Broken Window Theory}

The broken window theory suggests a connection between gentrification and crime based on both the physical conditions and perceptions of an area. Physical and social disorders (e.g. excessive litter, abandoned buildings, graffiti covered walls, public drug usage or drunkenness) create the impression that local residents do not care about their neighborhood in the mind of potential offenders (Wilson and Kelling 1982).Offenders are inspired by the belief that nobody will interfere with their unlawful activities or report delinquencies to the police (Zhang and McCord 2014).Social psychologists and police officers tend to agree that if a window in a car is broken and is left unattended, the rest of the cars will soon be stolen or vandalized (Wilson and Kelling 1982). One unrepaired broken window is a signal that no one cares, and so breaking more windows costs nothing (Wilson and Kelling 1982). Gentrification is the process in which "fractured windows would be repaired through refurbishment and maintenance, thus potentially ameliorates crime.

In the 1990s, the Giuliani-Bratton team instituted a policy of broken windows, which resulted in significant decreases in crime rate in New York City, with murder decreasing by 72 percent between 1990 and 1998 (Shelden 2004). Total violent crime went down by 51 percent (Shelden 2004). Uncertainty does exist as the broken windows policies lead to a drop in violent crime but violent crime decreased in every major city in 
the country including those in which policies other than broken windows were used (Shelden 2004). It is possible for urban neighborhoods to experience an increase in structural support without being displaced by providing affordable housing.

Unfortunately, the underlying advantage of increasing total land value is most important. An increase in neighborhood median household income would suggest that there are fewer broken windows in a neighborhood. The presence of coffee shops, breweries, distilleries, and wineries provide amenities and any temporal change in their distribution would suggest gentrification.

Routine activity theory, social disorganization theory, and broken window theory are exceptional at describing violent crimes at the neighborhood level. The lack of guardianship, the lack of community organization, and the prevalence of unkempt areas all tend to promote crime. The next section highlights the existing studies on the relationship between gentrification and crimes. It describes the reasoning for choosing the independent variables for this analysis.

Crime rates in most major U.S. cities increased between 1960 and 1980, and then declined dramatically during the 1990s (Barton 2014). Some literature points out that this coincides with the gentrification movement, which began to occur in nearly all U.S. cities during the 1980s and continued during the 1990s and 2000s (Barton 2014). In 2016, the presence of gentrification is readily apparent in Mid-Western cities including Louisville, KY. Cities such as Louisville are experiencing gentrification later than larger cities such as Chicago, New Orleans, and New York. The future of the urban environment is determined by the social structure that evolves from all processes involved. The prevalence of crime is key to a neighborhood's overall well-being as the level of total 
involvement (of its residents is directly related) is related. There is growing evidence that exposure to violent crime is highly damaging to children's cognitive functioning and performance in school (Sharkey et al. 2014). Neighborhoods that are experiencing high rates of crime are often low in education attainment, so an increase in education attainment would provide a decrease in violent crimes.

\section{Violent Crimes}

Homicide and robbery tend to function as strong indicators of the overall level of stability in a neighborhood (Papachristos et al. 2011). Homicide data have several advantages over the use of other crime measures because of two factors: (1) there is a close match between known homicides and the true number of homicides - that is, homicides are highly likely to be reported or discovered by police; and (2) homicide is less susceptible to definitional variation by the police (Papachristos et al. 2011). Robbery, on the other hand, can have a degree of definitional variation and occurs more frequently. The threat of robbery victimization has far-reaching effects on the quality of urban life through its influence on choices for residents and visitors about where to live, work, shop, and dine. As such, robbery operates as a measure of how "safe" a neighborhood feels to residents. (Papachristos et al. 2011) 


\section{GENTRIFICATION LITERATURE}

\section{Positive and Negative Perspectives}

Gentrification scholars generally agree that the process shapes the social composition and character of neighborhoods to the extent that each aspect was incorporated in identifying gentrification is greatly influenced by methodological differences (Barton and Gruner 2016). For instance, qualitative studies typically focused on individual gentrifying areas and emphasized the transition from traditional racial or ethnic neighborhood cultures to a uniform, middle-class, white culture (Barton and Gruner 2016; Freeman 2006; Anderson 1990). Qualitative findings can provide new ideas to a creative class of new geographers.

Many scholars have explored the behavior of crime rates within neighborhoods that are considered to have been completely gentrified or are still currently undergoing the process of gentrification (Barton and Gruener 2016; Sheppard 2015; Aikman 2014; Barton 2014; Skogan 1990; Covington et al. 1989). The differences in how people shed light on gentrification can lead to multiple assumptions on its direct and indirect impacts on neighborhood crime. As mentioned the phenomenon can be viewed as negative or positive. Gentrification can be either a toxin or a balm (Davidson 2014). Papachristos et al. (2011) provide neutrality as describing gentrification as a process that, for better or worse, changes neighborhoods. The overall impact on existing can be viewed as negative or positive amongst politicians, developers, city planners, and in the academics (Papachristos et al. 2011). A negative impact would be the displacement of lower income 
residents, which results in an increase in crime where they are relocated. A positive impact would be increased commercial activity. Research that tests this relationship has produced evidence of both negative and positive association between gentrification and crime (Papachristos et al. 2011).

\section{Gentrification: Decrease in Crime}

Certain studies have linked gentrification to a decrease in crime (Papachristos et al. 2011; Kreager, Lyons, and Hays 2007). These people see gentrification and urban renewal as being hand and hand, while revitalization can occur without displacement. They argue that gentrification is a way to revitalize a neighborhood's economy, cultural heritage, and social organization (Freeman 2006; Florida 2002). Gentrification draws middle class residents to the city by being attracted by job and recreational opportunities, low and appreciating housing prices, stabilization of negative social conditions (such as crime), and lifestyle or aesthetic considerations (Zuk et al. 2015). Barton (2014) found a negative association between gentrification with violent crime that was consistent with Papachristos et al. (2011), whose analysis focused on fixed-effects regression.

Gentrification in New York City was associated with a decline in violent crime rates over the past decade (Barton 2014). These studies provide the clearest basis for the underlying assumption of this paper: that change in alternative gentrification indicators (e.g. coffee shops and urban wineries) would result in a decrease in robberies and homicides.

Cortright (2015) focused on three studies that defended the process of gentrification. These include a study from NYU's Furman Center, the Philadelphia Federal Reserve Bank, and a Columbia University study on gentrification in London. The 
New York and Philadelphia studies both confirmed earlier research that gentrification is seldom associated with displacement, and that it is frequently associated with higher incomes and better economic results for the longtime residents of gentrifying neighborhoods (Cortright 2015). Residents tied the decrease in crime to the neighborhood's gentrification (Dastrup et al. 2015). The Columbia study tested multiple specifications of gentrification and examined displacement rates for low-income and working-class individuals (Freeman, Cassola, and Cai 2016). The results were inconsistent with the notion that gentrification leads to widespread direct displacement (Freeman, Cassola, and Cai 2016). The study from NYU's Furman Center found that many residents were fearful of gentrification driving up the cost of housing and leading to housing in the area being privatized (Dastrup et al. 2015). The study found that neighborhood residents felt that in the context of the surrounding higher-income neighborhoods, the developments were unfairly blamed for crime that originated at nearby nightclubs (Dastrup 2015).

Urban amenity locations could act in a similar manner. This correlation with a decrease in crime has become the bugle call for proponents of gentrification, who are attempting to outweigh the opposition. Several characteristics have contributed to the accelerated pace of gentrification in Philadelphia, PA. With a vibrant downtown and several strong anchor institutions (e.g., University of Pennsylvania and Temple University), Philadelphia has a relatively stable local economy and housing market (Ding et al. 2016). It is easy to advocate for gentrification if you are on the side that benefits from reinvestment. Local municipalities and real estate investors tend to gain from revitalization, but long existing residents receive few benefits from this process. 
Gentrification: Increase in Crime

In some studies, gentrification increased crime (Lee 2010; Van Wilsem, Wittebrod, and De Graaf 2006; Covington and Taylor 1989). Theories in the criminal justice literature,including routine activities and social disorganization, have suggested that gentrification results in short-term increases in crime because it disrupts the local social order (Barton and Gruner 2016). This disruption leads to decreased guardianship and social control in an existing community (Barton and Gruner 2016; Papachristos et al. 2011; Anderson 1990; Skogan 1990; McDonald 1986). The lack of social cohesion is apparent to long-term residents as they are forced to adhere to new affluent social organization. Businesses that provide amenities and experiences are associated with affluence.

Another impact from gentrification is that it does not help working-class communities and displaces poor residents (Freeman 2005; Freeman 2004; Smith 1996). Jasper (2016) states that "gentrification came into play after urban renewal policies devastated some inner-city communities and left entire neighborhoods open to redevelopment and resettlement as the previous residents were displaced to other sections of the city" (Jasper 2016,10). This displacement can easily apply pressure in other communities in an indirect way. The prior literature on the subject is inconclusive, but this is likely due to the various methodological approaches.

\section{Common Gentrification Indicators}

Understanding this process is inherently complex as the literature quickly realizes that one of the root difficulties is that what is considered as gentrified is subject to many 
different definitions and interpretations (Aikman 2014). Gentrification literature addressing the subject has been divided between empirical and theoretical approaches (Smith 1987). Quantitative studies have explored changes in larger samples of neighborhoods and frequently identified neighborhoods as gentrifiable or already gentrified if they featured specific characteristics (Barton and Gruner 2016). These characteristics include an extensive list of census-based measures of levels of education, income, residence cost, kinds of occupations, and other population characteristics (Hammel and Wyly 1996). To date, quantitative gentrification measures have relied almost exclusively on census data (Papachristos et al. 2011). This becomes problematic, as these characteristics are not available for all scales (e.g. census blocks, and census block groups). Qualitative and quantitative method choices vary across multiple disciplines such as geography, economics, sociology, and urban planning.

Schaffer and Smith (1986) examined several key indicators from the 1980 census for evidence of gentrification in Harlem. They examined changes over the decade in per capita income, median family income, median contract rent, and racial composition. It is also important to have a variable to identify a "mover." A "mover" is defined as an individual who lives in a census tract different from where he or she lived one year ago in this study (Ding et al. 2016). This is a measurement of residential mobility amongst a neighborhood. This is available from the ACS 5-year estimates, but does not detail if they moved in or out of the Census Tract. The computed variable describes the percentage that had simply moved in the prior year. 


\section{Alternative Gentrification Indicators}

Coffee shop locations can be used as a measurement that is specifically designed to capture subtle cultural process of neighborhood. Census indicators that are most common in the literature do not necessarily capture the subtle change (Papachristos et al. 2011). Papachristos et al. (2011) analysis used census-based gentrification measures with the multiyear average of coffee shops in a neighborhood. Papachristos et al. (2011) found that coffee shops are strongly related to declines in homicide and robbery. This suggests that they are an indication of the overall quality of a neighbored. Rehabilitation of buildings for commercial activity opens an avenue of speculation for both gentrifies and real estate developers (Zukin 2008). The perception of crime is lowered with the addition of friendly developments such as coffee shops.

Jeff Gordinier (2016) of the New York Times wrote a piece on the opening of Birch Coffee in the Southern Bronx. The coffee shops exposed brick, reclaimed wood and $\$ 2.75$ macchiatos made it an outlier on an area dominated by dime stores, bodegas and auto shops (Gordinier 2016). Coffee shops act as an early signal flare of gentrification (Gordinier 2016). Coffee shops were restricted to very affluent areas prior to the market leaning towards more historic portions of the city for both commercial and residential activities. Gentrification and the caffeine curse (Northeastern University2016) highlights the process of gentrification and links it to disposable income. New coffee shops open up in neighborhoods generally regarded as working class, but ironically only provides amenities such as single-origin pour-over coffee (Northeastern University 2016). Low income residents have little means to support coffee shops, thus a demographic change must have occurred. 
In recent years, the urban revival has seen an increase in newly opened breweries and distilleries that may be indications of gentrification alongside coffee shops. The city of Portland, Oregon, is synonymous with gentrification. There are 84 breweries operating in Portland, the most breweries of any city in the world (Pullman et al. 2015). Hopworks started production in 2007 in a refurbished old building that housed a brewpub on the premises (Pullman et al. 2015). Due to cost efficiency, once dilapidated areas are seen as advantageous. Matthew (2014) analyzed the relationship between brewpubs and gentrification. The literature is beginning to grow but there is still a lack of scholarly articles on the relationship between breweries and crime.

Louisville has seemingly experienced a renaissance in distillery operations. The Urban Bourbon Experience (UBE) has noted the hustle and new developments springing up on the original Whiskey Row and elsewhere with nearly a dozen bourbon-related ventures and $\$ 1$ billion in investment (UBE n.d.).The Bourbon and Food Work Group (BFWG) produced a report taunting the new visitor attractions that have sprung up, from the Evan Williams Bourbon Experience on Main Street to the re-opening of the historic Stitzel-Weller Distillery in Shively (BFWG n.d.). Between 2008 and 2013, Kentucky distillers spent well over $\$ 400$ million on capital improvement projects to increase production capacity and enhance the visitor experience. Despite the substantial investment in local projects, Kentucky or (Louisville) is behind the curve in craft distilling (Kornstein and Kelly 2013).

The investment has occurred in both large-scale distilling processes and smaller craft distilleries. Nationally, craft distilling began to take off in 2007, with five states (Washington, New York, Colorado, Oregon, and Texas) leading the way (Kornstein and 
Kelly 2013). Evan Williams Bourbon Experience is appropriately located on Louisville's whisky row as it combines an artisan distillery with an immersive educational experience. Brown-Forman's Old Forester Distillery, Michter's Distillery and the Angel's Envy Distillery have located on Market Street in Louisville (KDA 2014). The addition of tourism provides additional eyes in an area that had little surveillance. Crime could decrease, as distilleries are similar to breweries in that they indicate urban reinvestment that is often associated with gentrification. The urban winery boom is similar and has been mentioned alongside gentrification.

Wineries are setting up in cities, in converted industrial spaces, surrounded by asphalt instead of vines (Patterson 2007). Wilson T. VornDick (2014) of The American Association of Wine Economists highlights the Santa Barbara Winery that opened in 1964, as a practical and cost-efficient decision to combat against the prohibitively expensive and traditional rural winery-vineyard combination.

True to its urban appellation, the urban winery and movement has converged with the recent on-going gentrification and urban renewal taking place across America and abroad (VornDick 2014). In Louisville, the Old 502 Winery has become a prominent urban winery that offers tours and rental space. It is located on 10th street, which is two blocks away from the Louisville central business district (CBD). Urban wineries may be uniquely positioned to better capture the economic benefits because of their location and geographic proximity to the urban and sub-urban customers in comparison to their rural counterparts (McKinsey 2008). The location of the Old 502 Winery would seem more appealing to the newly arrived urbanites due to its nature of being a local product. 
A workable way to obtain geographically referenced data on business locations including coffee shops, breweries, distilleries, and wineries is to us city inventories. Form and Dubrow (2008) used city directories to locate churches is Ecology of Denominational Fundamentalism in a Metropolis. Similarly, we can compile the location of all business that share a similar market. A variety of studies that incorporate addresses or telephone numbers have used local city directories. Sung-suk Violet Yu (2009) used Verizon’s Yellow Book to compile a dataset of businesses (Yu 2009). The use of the phonebook database to measure business locations is not time-consuming ( $\mathrm{Yu}$ 2009). The location of coffee shops, breweries, distilleries, and wineries are accurately mapped based on their addresses. Their spatial distribution can provided new insight on the measurement of social phenomenon.

Lee and Goulias (1996) compiled phone numbers from yellow page and white page directories to for a GIS-based accessibility analysis. Addresses can be verified more precisely using local maps and a city directory to determine their eligibility (Vine, Degnan, and Hanchette 1997). Papachristos et al. (2011) counted the total number of coffee shops in a neighborhood each year from 1991 to 2004 from all listings under "Coffee \& Tea" and "Coffee Shops" in annual Chicago Business Directories. Geocoding addresses from a local business directory is permitted for a GIS analysis (McCormack 1999). 


\section{DATA}

Three data categories were compiled from multiple data sources. The first data set describes the location of violent crimes: homicides and robberies. This is from the Louisville Metro Police Department (LMPD) and includes addresses from 2010 to 2015. The second data set consists of nine Census variables that are commonly used in the literature to define gentrification (Papachristos et al. 2011). The third dataset consists of alternative gentrification indicators described in the literature. These are derived from cross-referencing local and regional business directories; this information is derived from three sources: Kentucky Business Directories from ReferenceUSA (2010 -2016), the yellow pages, and restaurant inspection scores from LouisvilleKY.gov. The combination of the three provide the information to measure gentrification and crime using the alternative indicators described in the literature. These alternative gentrification indicators will also be a measurement of the quality of a neighborhood based on the contemporary desires of the current market. It is important to note that the census tract that contains the entire Louisville International Airport was excluded from the study as there is no population. The following sections highlight the data sources.

\section{Crime Data}

With the Mayor's Open Data Executive Order in partnership with the White House Police Data Initiative, the Louisville Metro Police Department (LMPD) is committed to increasing the openness and transparency of the government to the citizens 
of its community by sharing police data in an open format (lmpd.org). This dataset contains many different types of homicides and robberies. Following an approach used by Papachristos et al. (2011), we collected data for two types of data including the multiyear average of homicides and street robberies in Louisville Metro. The data set was provided by the LMPD Crime Information Center (CIC). The data provided by the LMPD CIC is accurate to the exact dwelling or street corner.

For this study, 13,107 robberies were geocoded from 2010 to 2016 . For the same time duration, there were 467 homicides. The dependent variables used for OLS and GWR are multiyear average rates based on these counts from 2010 to 2016.

\section{Common Gentrification Indicators}

The US Census Bureau provides several demographic and key social and cultural characteristics that can be used to proximate the process of gentrification. Every community in the nation receives a detailed statistical portrait of its social, economic, housing and demographic characteristics through 1-year, 3-year, and 5-year ACS products (Census 2016). The dataset chosen for this study were the American Community Survey (ACS) 2015 5-year estimates. The information was collected at the census tract level as the 5-year is the most reliable at a smaller geographic scale in comparison to other ACS datasets available. The use of administrative units of analysis in neighborhood based research is often done out of convenience (Kirk and Laub 2010). Census tracts are considered as reasonable, although imperfect, proxies for city neighborhoods (Bostic and Martin 2003). The following seven variables were determined as key demographic and economic indicators for gentrification as highlighted by Papachristos et al. (2011).The 
seven variables derived from the ACS 2015 5-year estimates include (1) education attainment as measured by those with a bachelor's or higher for population aged 25 or over, (2) median household income, (3)percentage of residents in poverty, (4) percentage of housing vacancies, (5) percentage of unemployment, (6) percentage of minorities , and the (7) percentage of residents that have moved within the past 12 months.

\section{Alternative Gentrification Indicators}

This study cross-referenced a Kentucky regional business directory from ReferenceUSA, the local business directory form the YellowPages, and restaurant scores provided from Metro Louisville. The later was used to confirm recent coffee shop openings in 2016 in the Portland neighborhood, which is located in the northwest part of the county. The regional and local business directories were cross-referenced for the address for breweries, distilleries, and wineries.

This study assumes that the location of coffee shops, breweries, distilleries, and wineries are locations that provide high amenities. This description allows the model to use a temporal control variable, allowing for a comparison of change over time. A gentrification variable consist of the total count of coffee shops in both 2010 and 2016, as well as listings for breweries, distilleries, and wineries in 2010 and 2016. There were 69 coffee shops for 2016 and 22 breweries, distilleries, and wineries in 2016. In 2010, there were 66 coffee shops and 12 breweries, distilleries, and wineries in 2010. Figure 2 shows the 2010 and 2016 locations that are used to compute the two independent variables. The two variables were used for neighborhood quality and an alternative gentrification indicator. Figure 3 shows the displayed in a choropleth map using a five class natural 
breaks method for the combinations of these alternative gentrification indicators for both 2010 and 2016. Figure 4 shows the change in these indicators from 2010 to 2016. 
- Breweries, distilleries, and wineries (2010)

- Coffee Shops (2010)

$\square$ Census tract bouundary

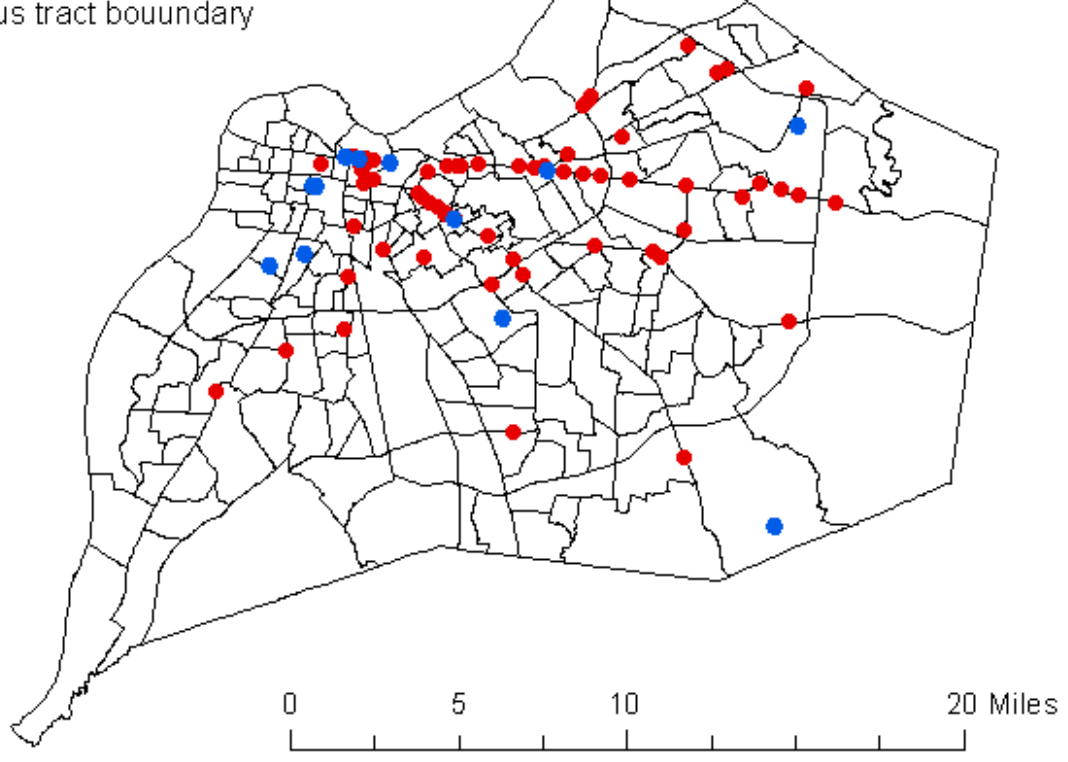

- Breweries, distilleries, and wineries (2016)

- Coffee Shops (2016)

$\square$ Census tract boundary

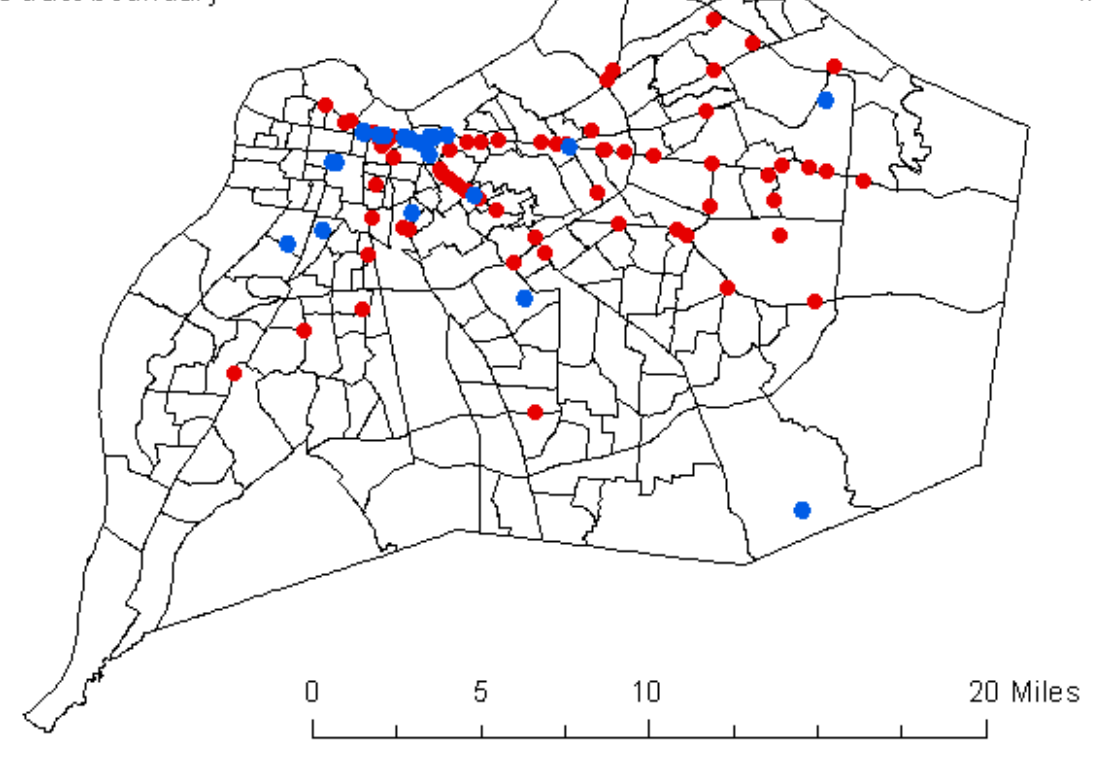

Figure 2. 2010 and 2016 urban amenities used to compute the two independent variables (urban amenity locations and alternative gentrification indicator). 
Total count of coffee shops, breweries, wineries, and distilleries (2010)
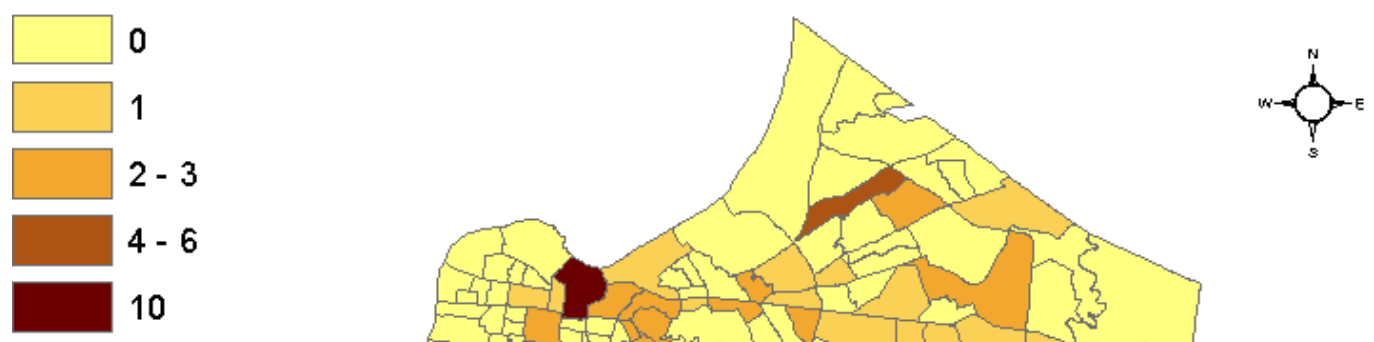

$-6$

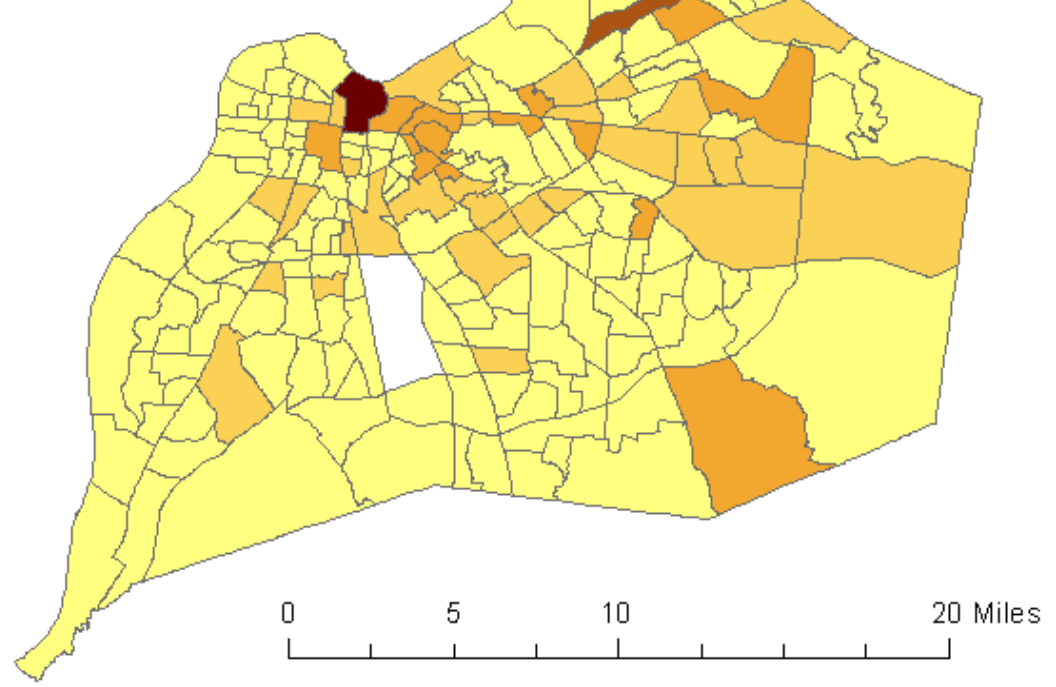

Total count of coffee shops, breweries, wineries, and distilleries (2016)
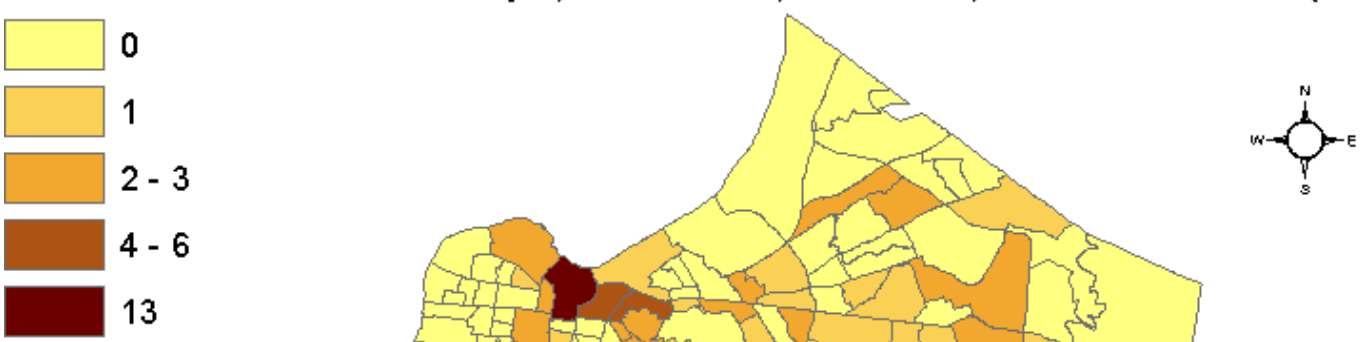

13

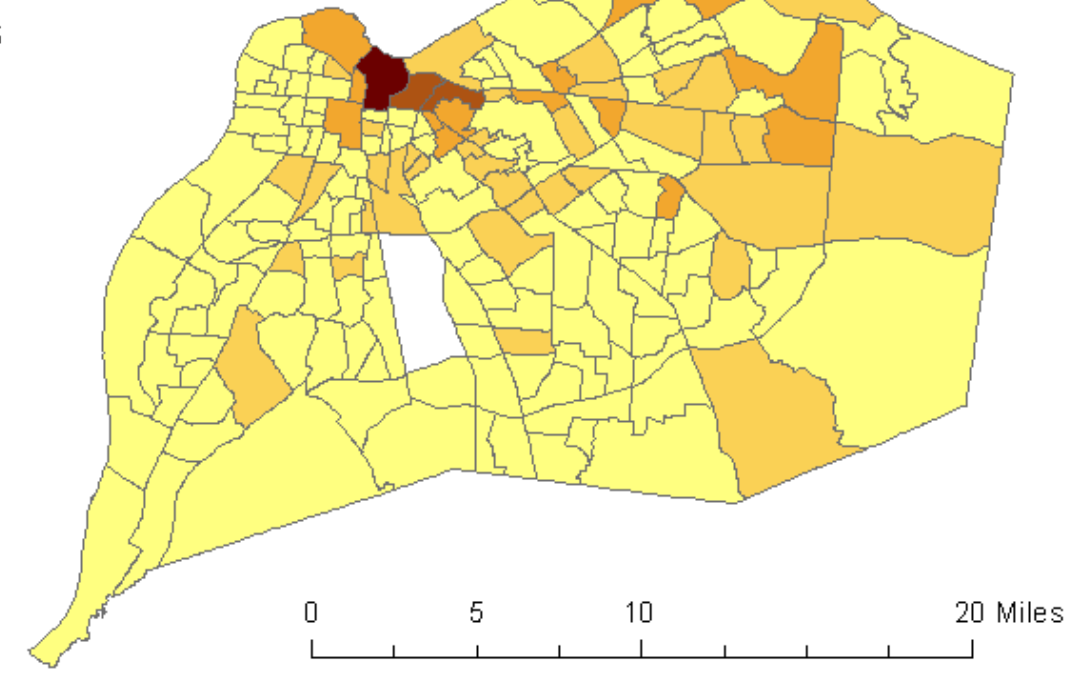

Figure 3. Choropleth maps showing the distribution of urban amenities for 2010 and 2016. 
Change in total count of coffee shops, breweries, distilleries, and wineries from 2010 to 2016

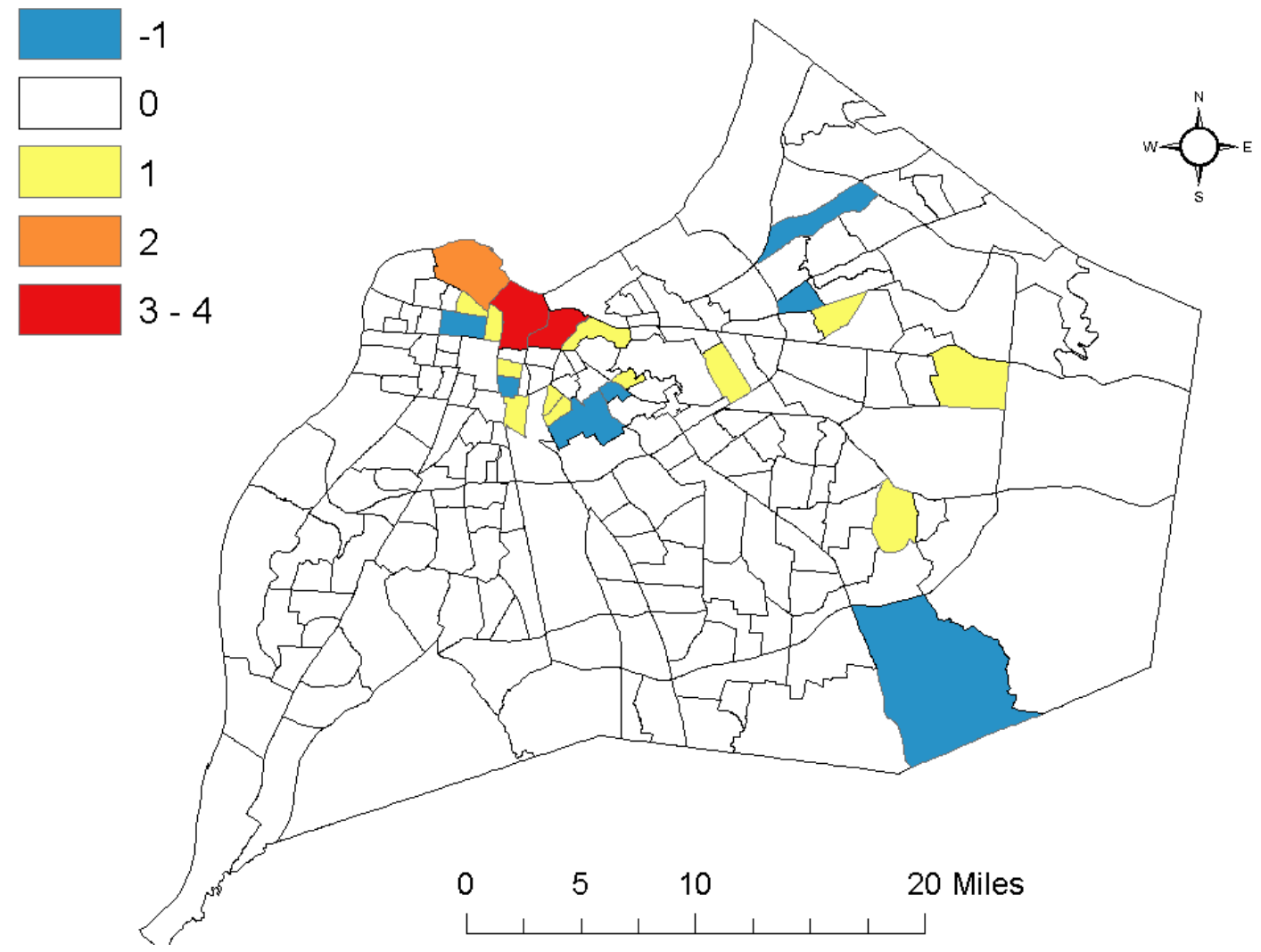

Figure 4. Alternative gentrification indicators; change in the total count of urban amenities from 2010 to 2016.

Figure 2, figure 3, and figure 4 show that the variables are associated with the CBD and adjacent neighborhoods. Figure 4 shows haw these indicators are also found in sub-divided neighborhoods. Thus, the entire county is acceptable for spatial analysis. 


\section{METHODS}

A study by David Ley (2003) measured the concentration of artists and their effect on gentrification using census tracts in Toronto, Canada. The analysis of census data at the tract-level for gentrification has is benefits. Papachristos et al. (2011) used a clustered combination of census tracts that translated to neighborhoods. This was based on the Project on Human Development in Chicago Neighborhoods, which created neighborhood clusters by combining the 847 census tracts into geographically contiguous areas that were internally homogenous on key census indictors of race/ethnicity, housing density, and family structure (Sampson et al. 1997).The methodological process consists of mapping the spatial distribution of variables, a descriptive analysis of the statistics, two OLS regression for multi-year average robbery and homicide rates. A Moran's-I was conducted for the OLS results to test for spatial autocorrelation. Then the two dependent variables are analyzed using a Geographically Weighted Regression (GWR) model to account for locality. A second Moran's-I was calculated for the GWR models for model comparison with the OLS.

The methods were aided by software programs such as ArcMap 10+ and Microsoft Excel. Demographic and mapping provides the basic understanding for the distribution of both independent and dependent variables. GIS maps provide a quick and clear means of detecting the precise location of environmental improvements and deterioration just as they have been widely used to identify crime hot spots in neighborhoods (Perkins et al. 2009). This step was conducted in ArcMap and provides a 
visual representation of gentrification and crime distribution across the county.

Choropleth maps depicted by a natural breaks classification can show spatial variations across Louisville, KY.

Map-oriented researchers have long been interested in data description and induction, usually searching the statistics literature for ideas on how to extract as much information as possible from georeferenced data. The field of spatial statistics is based on the non-independence of observations; that is, the research is based on the assumption that nearby units are in some way associated (Tobler 1979). Spatial statistics provide the evidence that can lead to rational decision making. Geographic information systems are well suited for the exploration and manipulation of spatial data. There are benefits of taking into account spatial patterns in the analysis of social science data (Ward and Gleditsch 2007). This allowed an analysis that incorporates a spatial understanding of the level of violent crimes as neighborhoods evolve.

An ordinary least squares (OLS) regression line through all of these standardized observations produced a summary measure of the relationship between the values of the dependent variable and the included independent variables (Ward and Gleditsch 2007). Papachristos et al. (2011) tracked changes in the neighborhood conditions by utilizing ordinary least squares regression of the 1990 census factors on the 2000 census. An OLS regression model was conducted for both multiyear average robberies rates and multiyear average homicide rates for their relationship with the eleven independent variables. The detection of spatial autocorrelation is measure by Moran's-I. For the Moran's-I, the values of the target feature and the neighboring feature are both compared to the means (Mitchell 2005). A large positive value indicates clustering of similar values, and a large 
negative value indicates that a feature is surrounded by distant values (Mitchell 2005). The Moran's-I was calculated for the residuals of multiyear average of robberies and multiyear average of homicides respectively.

GWR works by allowing model coefficients to vary regionally (Mitchell 2005). A regression for each location provides a local model, as opposed to a global model that consider the entire study area as a whole (Mitchell 2005). This allows for a finer and more appropriate analysis of the gentrification indicators, as they are extremely clustered towards the inner city but dispersed in the periphery. The model produces a R2 value for each location, and the coefficients and R2values can be can be mapped to get a sense of the relationship between dependent and independent variables (Mitchell 2005). The combination of OLS and GWR for both dependent variables describe the variation of violent crime rates in Louisville, KY as described by both common gentrification indicators and alternative gentrification indicators. 


\section{RESULTS}

\section{Descriptive Statistics}

The majority of the independent variables demonstrate an East to West division between areas with high incomes in the East. The disparities in the data are depicted by descriptive statistics (Table 1). The descriptive statistics demonstrates the minimum, the maximum, the mean, and the standard deviation for all variables conducted in this analysis including the two dependent variables and eleven independent variables that were used in the subsequent OLS and GWR analyses. It provides a fist look at the variation amongst the variables across the study areas. Table 2 provides the chronological change for selected LMPD and US census variables to help describe the process. Both provide to the narrative, describing the variation amongst census tracts for both their status and their transition over time.

The multiyear average of robberies across census tracts shows a large degree of disparities in Louisville. Looking at robberies per year, the minimum value of 0 robberies a year per census tract describes an affluent neighborhood with organization. The maximum for the variable is 66.71 robberies a year per census tract. There are three census tracts that have an average of more than 50 robberies per year, and all are located in the inner city. The three census tracts were (1) census tract 24 (66.7 robberies per year) that is associated with the West Russell neighborhood, (2) census tract 49 (65.7 robberies per year) that is associated, with the $\mathrm{CBD}$ and census tract 27 (52.1 robberies per year) that is associated with the California neighborhood. The mean for robberies a year per 
census tract was 9.7 from 2010 to 2016 . This shows that robberies are highly

concentrated in the inner city, which is prime real estate for gentrification. The two neighborhoods listed (West Russell and California) are predominantly low income and have a high percentage of minority residents.

Table 1. Descriptive Statistics of Dependent and Independent Variables

\begin{tabular}{|l|c|c|c|c|}
\hline Variables & Minimum & Maximum & Mean & $\begin{array}{c}\text { Standard } \\
\text { deviation }\end{array}$ \\
\hline Robberies (multiyear average) & 0 & 66.71 & 9.7 & 10.95 \\
\hline Homicides (multiyear average) & 0 & 2.71 & 0.33 & 0.5 \\
\hline $\begin{array}{l}\text { Urban Amenities - Coffee shops, } \\
\text { breweries, distilleries, and }\end{array}$ & 0 & 13 & 0.47 & 1.22 \\
\hline $\begin{array}{l}\text { wineries (2016) } \\
\text { Alternative Gentrification Indicator - } \\
\text { Change from 2010 to 2016 }\end{array}$ & -1 & 4 & 0.07 & 0.5 \\
\hline $\begin{array}{l}\text { Education Attainment (Bachelors or } \\
\text { higher 25 and over) }\end{array}$ & 2.4 & 77.6 & 29.9 & 20.9 \\
\hline Median Household Income (US \$) & 9,439 & 140,156 & 51,345 & $25,577.40$ \\
\hline Poverty rate (\%) & 0.7 & 84.5 & 19.2 & 14.39 \\
\hline Unemployment rate (\%) & 1.3 & 38.6 & 9.4 & 6.5 \\
\hline Vacancy Rate (\%) & 0 & 34.6 & 10.2 & 7.4 \\
\hline Commercial Land Use (\%) & 0 & 36.8 & 7.9 & 6.9 \\
\hline Multifamily Land Use (\%) & 0 & 27.6 & 5.5 & 5.5 \\
\hline Moved within the past year (\%) & 3.9 & 53.2 & 15.1 & 7.3 \\
\hline Minority rate (non-white) (\%) & 1.4 & 98.8 & 28.8 & 26.2 \\
\hline
\end{tabular}


Table 2. Descriptive Statistics for the change between selected LMPD and US census variables

\begin{tabular}{|l|c|c|c|c|}
\hline Variables & Minimum & Maximum & Mean & $\begin{array}{c}\text { Standard } \\
\text { deviation }\end{array}$ \\
\hline $\begin{array}{l}\text { Change in Robberiecounts from } \\
2010 \text { to } 2016\end{array}$ & -36 & 39 & -0.2 & 7.92 \\
\hline $\begin{array}{l}\text { Change in Homicide counts from } \\
2010 \text { to } 2016\end{array}$ & -2 & 6 & 0.31 & 1.11 \\
\hline $\begin{array}{l}\text { \% change in Education Attainment } \\
\text { from 2010 to 2015 }\end{array}$ & -15 & 23.7 & 2.94 & 5.5 \\
\hline $\begin{array}{l}\text { \% change in Median Household } \\
\text { Income (US \$) from 2010 to 2015 }\end{array}$ & $-15,617$ & 50,599 & 3,468 & $8,081.30$ \\
\hline $\begin{array}{l}\text { \% change of residents in poverty } \\
\text { from 2012 to 2015 }\end{array}$ & -23.7 & 20.9 & -0.32 & 6 \\
\hline $\begin{array}{l}\text { \% change in unemployment from } \\
2010 \text { to } 2015\end{array}$ & -31.4 & 14.5 & -0.67 & 6.2 \\
\hline $\begin{array}{l}\text { \% change in Vacancy from 2010 to } \\
2015\end{array}$ & -16 & 15.6 & -0.17 & 5.7 \\
\hline $\begin{array}{l}\text { \% change in residential mobility } \\
\text { from 2010 to 2015 }\end{array}$ & -20.48 & 15.94 & -1.27 & 6.77 \\
\hline $\begin{array}{l}\text { \% change in Minority population } \\
\text { from 2010 to 2015 }\end{array}$ & -23.74 & 23.4 & 1.23 & 7.24 \\
\hline
\end{tabular}

The multiyear average for Homicides from 2010 to 2016 ranged from zero (minimum) to 2.71 (maximum) for multiyear average of homicides across the census tracts. The census tracts that have an average of zero homicides per year distributed across the suburban East and South East parts of the city where there is no possibility of gentrification. Table 2 demonstrates that a census tract experienced a decline of 36 robberies from 2010 to 2016 . At the maximum end, there was an increase of 39 robberies from 2010 to 2016. Four census tracts averaged more than two homicides a year. These 
included (1) census tract 24 associated with the West Russell Neighborhood, (2) census tract 30 associated with the East Russell Neighborhood, (3) census tract 10 associated with the Parkside Neighborhood, and (4) census tract 16 associated with the Algonquin Neighborhood. For all census tracts, the mean for homicides was 0.33 , which is much lower than the three highest averages. All four-census tracts listed are predominantly low income and have a high percentage of minority residents. Both robberies and homicides are clustered amongst the inner city.

In Louisville, the quantification of these indicators (e.g. Coffee shops, breweries, distilleries, and wineries) have increased from 77 to 91 locations during the period of 2010-2015. This suggest an overall increase in the quality of neighborhoods in the city. The majority of census tracts with a high number of alternative gentrification indicators would be the CBD and the neighborhoods directly to the East end. The descriptive statistics demonstrated a major variation between the distribution of alternative gentrification indicators (e.g. distilleries, and coffee shops) across census tracts.

The minimum value is zero, and the majority of census tracts (137 of 190) do not have a coffee shop, a brewery, a distillery, or a winery. The maximum value is 13 alternative gentrification indicators. The mean for all tracts is (.47). The maximum amount (13) of locations are found in census tract 49 that is associated with the CBD. As expected, nine of the 13 locations are coffee shops. Census tract 59 has 6 total indicators and is associated with the Phoenix Hill and Butcher town Neighborhoods directly east of the CBD. This area has adopted new name, NULU as a means to re-brand the area. Census tract 59 has two coffee shops, three breweries and one distillery. Census tract 81 had the third highest count with four alternative indicators, an area associated with the 
Irish Hill Neighborhood and the Clifton Neighborhood. The census tract includes two breweries and two coffee shop listings. Of the three areas mentioned, the CBD was the only see a reduction in median household income, suggesting an increase in affordable housing or simply an increase in the housing stock. The second and third highest counts of alternative gentrification indicators are found in neighborhoods that have witnessed a surge in median household income from 2010 to 2015.

The descriptive statistics shown in table 1 show that the change in the total count of alternative gentrification indicators (e.g. coffee shops, and wineries) from 2010 to 2016 has a maximum value of 4 and a minimum of (-1). This independent variable offers a temporal understanding of this urban transformation, as a census tract demonstrating a negative would suggest a lack of investment, which would help facilitate violent crimes. The addition of 4 indicators to census tract 59 from 2010 to 2016 suggests that the NuLu neighborhood has undergone gentrification. This area has been rebranded and has seen an increase from 2 indicators in 2010 to 6 indicators in 2016. The previous paragraph explains the distribution of these indicators in this area. There were a total of 15 census tracts that reported a positive increase in the total count of gentrification indicators. 11 of the 15 are found in the inner city. There were seven census tracts scattered across the city that reported a negative loss of one indicator from 2010 to 2016 . The change in the total number of alternative gentrification indicators suggests that these commercial activities are re-centralizing near the CBD. This transition corresponds with urban renewal and revival efforts in neighborhoods that were once deemed blighted, but have recently become trendy. 
The remaining nine independent variables continue to describe Louisville as a highly segregated city. The division between census tracts with the lowest and highest education attainment rates ranged from $2.4 \%$ to $77.6 \%$ of the population (over the age of 25 ) with a bachelor's degree or a higher. There were 37 census tracts in which less than $10 \%$ of the population (over the age of 25 ) had earned a bachelor's degree or higher. The distribution of Median Household Income is drastically different. The minimum is $\$ 9,439$ and the maximum is $\$ 140,156$. The lower median household incomes are found in the West and South West, while the higher median household incomes were found in the East.

The percentage of people in poverty and the percentage of unemployment are spatially similar to education attainment rates and the distribution of median household incomes. Poverty percentage is as high as 84.5 percent and as low as 0.7 percent. Seven census tracts had at least a 50 percent poverty rate, and all can be found in the inner city. The distribution of unemployment has a smaller distribution with a minimum value of 1.3 percent and a maximum value of 38.6 percent. Once again, the higher unemployment rates for census tracts are commonly found around the CBD and in the West. The distribution of vacancy rates has a similar distribution as unemployment rates. The minimum value 0 , but three maximum values is 34.6 percent vacancy rate. There were three census tracts, all located in the inner city, that had vacancy rates higher than 30 percent in 2015. The broken window theory helps connect high vacancy rates with violent crimes.

The distribution within the percentage of minorities is most telling of the high segregation. Table 1 lists that the maximum in the percentage of minorities in a census 
tract was 98.8 percent, and the minimum was 1.4 percent. The mean is 28.8 percent. Areas with a high concentration of minorities are associated with high crime rates. Poverty, unemployment, and vacancies rates are also present.

Residential mobility as measured by the percentage of residents that have moved in the past 12 months has a maximum value 53.2 percent and a minimum value of 3.9 percent. The CBD obtains the maximum percentage of people moving in the past 12 months. The distribution is similar to the two independent land-use variables, the percentage of commercial land use and percentage of multiple family land use and commercial land use that ranged from $0 \%$ to $36.8 \%$ in 2015 , and from $0 \%$ to $27.6 \%$ respectively. Census tracts with a high percentage of commercial land use are most common in the suburbs. High percentage of Multiple Family land use is scattered across the city and is mainly associated with the road network. The descriptive statistics showed dramatic spatial variation in regards to violent crimes, census variables chosen and the location of alternative gentrification indicators across Louisville's census tracts. Visualizing the spatial distribution of these variables allows a basic understanding of the relationship between gentrification and violent crime. A statistical analysis of both homicides and robberies would provide a further understanding about their relationships with neighborhood gentrification along with other contextual socioeconomic variables. Their relationships with multiyear average homicide and multiyear average robbery rates would provide insight on how neighborhoods will be changing in regards to violent crimes. 


\section{Robberies: OLS Regression}

The OLS results show a very capable model for analyzing the correlates of variations of robberies across census tracts in Louisville Metro. For the first regression model, the multiyear average rate of robberies received a $\mathrm{R} 2$ value of .67 , and an adjusted $\mathrm{R} 2$ value of .65.This means that 65 percent of the spatial variation of multiyear average robbery rates per census tract was explained by the independent variables used in this analysis. None of the independent variables have a VIF over 7.5, confirming that there is no redundancy amongst the independent variables. The Koenker (BP) value of 34.72 is significant with a p-value of .0003 , confirming the presence of non-stationarity or heteroscedasticity meaning the relationship between the dependent variable and each of the independent variables is not consistent across the entire study area. A significant BP value means to consult the robust $\mathrm{p}$-values and robust coefficients for the effectiveness of the variables. There were four significant coefficients: the gentrification indicators $(+2.97)$ (a collective measure of four types of urban amenities including coffee shops, breweries, distilleries, and wineries), percentage of vacancies $(+.32)$, percentage in poverty (+.27), and percentage of minorities (+.07) (non-whites). The significant relationships are not consistent with the original hypotheses that coffee shops decrease crime rates. The OLS model shows a positive relationship between multiyear average robberies and out indicators of neighborhood wellbeing. However, there are doubts surrounding this global model and its ability to describe the spatial variation between annual robbery rates and the independent variables. Due to the significance of the BP value, a more localized model such as GWR would provide a clearer understanding of the study area. 
Table 3. Results of OLS regressions analysis for robberies (multiyear average) from 2010 to 2016

\begin{tabular}{|c|c|c|c|}
\hline Independent Variable & Coefficient [a] & Probability [b] & Standard Error \\
\hline Intercept & -1.4 & 0.62 & 2.9 \\
\hline $\begin{array}{l}\text { Urban Amenities (e.g. Coffee shops, breweries, } \\
\text { distilleries, \& wineries) }\end{array}$ & 2.97 & $.000012^{* * *}$ & 0.65 \\
\hline $\begin{array}{l}\text { Alternative Gentrification Indicators from } \\
2010 \text { to } 2016\end{array}$ & -2.24 & 0.24 & 1.89 \\
\hline $\begin{array}{l}\text { Education Attainment (Bachelors or higher } 25 \\
\text { and over) }\end{array}$ & -0.04 & 0.21 & 0.03 \\
\hline Median Household Income (US\$1000) & -0.005 & 0.86 & 0.03 \\
\hline$\%$ Poverty & 0.27 & $0.01 * * *$ & 0.09 \\
\hline$\%$ Unemployment & 0.13 & 0.55 & 0.22 \\
\hline$\%$ Vacancy & 0.32 & $.001^{* * *}$ & 0.09 \\
\hline$\%$ of Commercial Land Use & 0.02 & 0.85 & 0.09 \\
\hline$\%$ of Multi-Family Land Use & 0.01 & 0.88 & 0.09 \\
\hline Residential Mobility & -1.11 & 0.89 & 8.1 \\
\hline$\%$ of minorities (Non-White) & 0.07 & $0.02 * *$ & 0.03 \\
\hline Akaike's Informtion Criterion (AIC) & 1264.35 & & \\
\hline $\mathrm{R}^{\wedge} 2$ & 0.67 & & \\
\hline Adjusted $\mathrm{R}^{\wedge} 2$ & 0.65 & & \\
\hline
\end{tabular}

\section{Homicides: OLS Regression}

The OLS results showed a very capable model for describing the geographic distribution of gentrification as described by the independent variables and their spatial relationship with multiyear average homicide rates across census tracts. This model displays an adjusted R2value of .65, which means that 65 percent of the spatial variation of the dependent variable is described by the collective independent variables. As mentioned, the adjusted R2value provides the most accurate determination as it factors in 
the eleven descriptors. None of the independent variables had a VIF higher than 7.5, confirming that multi-collinearity was not a concern among the independent variables. The variables chosen are well equipped for describing the process of gentrification in relationship to multiyear average homicide rates.

There is not a significant relationship with multiyear average homicide rates and alternative gentrification indicators as measured by coffee shops, breweries, distilleries, and wineries, and the change in gentrification indicators. There is also no significant relationship between multiyear average homicides and the change in the total count of these alternative gentrification indicators from 2010 to 2016.

There were five significant coefficients: the percentage of residents that have moved within the past year (-0.94), percentage of unemployment (+.02), percentage of vacancies (+.01), percentage of poverty $(+0.01)$, and percentage of minorities $(+.01)$. The significant relationship between the mobility of residents and multiyear average homicide rates is negative. This suggests that people with the ability to move are in areas that have fewer homicides. The adjusted R2 confirms that 65 percent of the total spatial variation of multiyear homicide rates per census tract are explained by the independent variables used in this analysis. The Koenker (BP) value of 57.5 that is significant with a p-value of .0000 , confirming that the model displays non-stationarity or heteroscedasticity. This means that the relationship between the dependent variable and each of the independent variables is not consistent across the entire study area. In addition, the AIC value is very low at 94.54, suggesting a desirable fit. A more localized model such as Geographic Weighted Regression would provide a clearer understanding of relationship between 
gentrification as described by the independent variables and the multiyear average of homicide from 2010 through 2016.

For the GWR models, the two prior OLS models confirmed that the independent variables indicators are able to account for a good portion of the variation of both violent crimes from 2010 to 2016. Unfortunately, it does not have the capability to take into account any spatial autocorrelation. The GRW mode take into account the local variations amongst the census tracts by taking into account the proximity of crimes. At this point, it would be ill advised and irrational to declare that the OLS model predicts that alternative gentrification indicators increase crime because that correlation does not necessarily equals causation. All of the crime is concentrated in the inner city. A GWR analysis in ArcGIS helps further understand the relationship between gentrification as measured by the independent variables and violent crimes. 
Table 4. Results of OLS Regression analysis for homicides (multiyear average) from 2010 to 2016

\begin{tabular}{|c|c|c|c|}
\hline Independent Variable & Coefficient [a] & Probability [b] & Standard Error \\
\hline Intercept & -1.4 & 0.62 & 2.9 \\
\hline $\begin{array}{l}\text { Urban Amenities (e.g. Coffee shops, breweries, } \\
\text { distilleries, \& wineries) }\end{array}$ & 2.97 & $.000012^{* * *}$ & 0.65 \\
\hline $\begin{array}{l}\text { Alternative Gentrification Indicators from } \\
2010 \text { to } 2016\end{array}$ & -2.24 & 0.24 & 1.89 \\
\hline $\begin{array}{l}\text { Education Attainment (Bachelors or higher } 25 \\
\text { and over) }\end{array}$ & -0.04 & 0.21 & 0.03 \\
\hline Median Household Income (US\$1000) & -0.005 & 0.86 & 0.03 \\
\hline \% Poverty & 0.27 & $0.01 * * *$ & 0.09 \\
\hline$\%$ Unemployment & 0.13 & 0.55 & 0.22 \\
\hline$\%$ Vacancy & 0.32 & $.001 * * *$ & 0.09 \\
\hline$\%$ of Commercial Land Use & 0.02 & 0.85 & 0.09 \\
\hline$\%$ of Multi-Family Land Use & 0.01 & 0.88 & 0.09 \\
\hline Residential Mobility & -1.11 & 0.89 & 8.1 \\
\hline$\%$ of minorities (Non-White) & 0.07 & $0.02 * *$ & 0.03 \\
\hline Akaike's Informtion Criterion (AIC) & 1264.35 & & \\
\hline $\mathrm{R}^{\wedge} 2$ & 0.67 & & \\
\hline Adjusted $\mathrm{R}^{\wedge} 2$ & 0.65 & & \\
\hline
\end{tabular}

\section{Robberies: GWR}

The following table 4 demonstrates the minimum, median, and maximum regression coefficients for independent variables for all 190 census tracts analyzed for their relationship with multiyear average robbery rates. The GWR results produce a coefficient and standard error for each individual census tract. A T-test was calculated in ArcGIS and found significance for the first hypothesis, as both the alternative gentrification indicators and the change in the total count of alternative gentrification 
indicators form 2010 to 2016 had significant median t-test scores. Not all census tracts displayed a significant relationship with both key independent variables. The change over time variable displays a negative coefficient suggesting a negative relationship with homicide rates. Not all census tracts were significant as the model predicts that the Western and South Western census tracts would have a negative relationship with the change in robbery rates from 2010 to 2016 . The localized GWR model can predict this with enough significance to confirm the first hypothesis that state homicides would decrease with the increase of alternative gentrification indicators. The results also tell me that the alternative gentrification indicators are locating in areas with high robbery rates in comparison to other areas of Louisville. This is most likely due to the fact that the amount commercial land use has increased in these areas, providing lanes of opportunity. The results are displayed in table 5. 
Table 5. Results of GWR analysis for robberies (multiyear average) from 2010 to 2016.

\begin{tabular}{|c|c|c|c|}
\hline \multirow[t]{2}{*}{ Independent Variable } & \multicolumn{3}{|c|}{ Coefficient } \\
\hline & Min & Med & Max \\
\hline Intercept & -3.35 & -1.74 & -0.46 \\
\hline $\begin{array}{l}\text { Urban Amenities (e.g. Coffee shops, breweries, distilleries, \& } \\
\text { wineries) }\end{array}$ & 1.9 & $3.21 *$ & 3.85 \\
\hline Alternative Gentrification Indicators from 2010 to 2016 & -4.26 & $-2.37^{*}$ & -0.45 \\
\hline Education Attainment (Bachelors or higher 25 and over) & -0.06 & -0.4 & -0.03 \\
\hline Median Household Income (US\$1000) & -0.007 & 0.002 & 0.007 \\
\hline$\%$ Poverty & 0.16 & $0.27^{*}$ & 0.32 \\
\hline$\%$ Unemployment & 0.03 & 0.14 & 0.24 \\
\hline$\%$ Vacancy & 0.22 & $0.33^{*}$ & 0.39 \\
\hline$\%$ of Commercial Land Use & -0.07 & 0.01 & 0.14 \\
\hline$\%$ of Multi-Family Land Use & -0.11 & 0.03 & 0.29 \\
\hline Residential Mobility & -5 & -0.48 & 2.13 \\
\hline$\%$ of minorities (Non-White) & 0.04 & $0.07^{*}$ & 0.13 \\
\hline Local $\mathrm{R}^{\wedge} 2$ & 0.52 & 0.68 & 0.75 \\
\hline Akaike's Informtion Criterion (AIC) & 1258.84 & & \\
\hline$R^{\wedge} 2$ & 0.7 & & \\
\hline Adjusted $R^{\wedge} 2$ & 0.67 & & \\
\hline
\end{tabular}

*significance is based on median coefficient T-test (>1.96 or $<-1.96)$ 


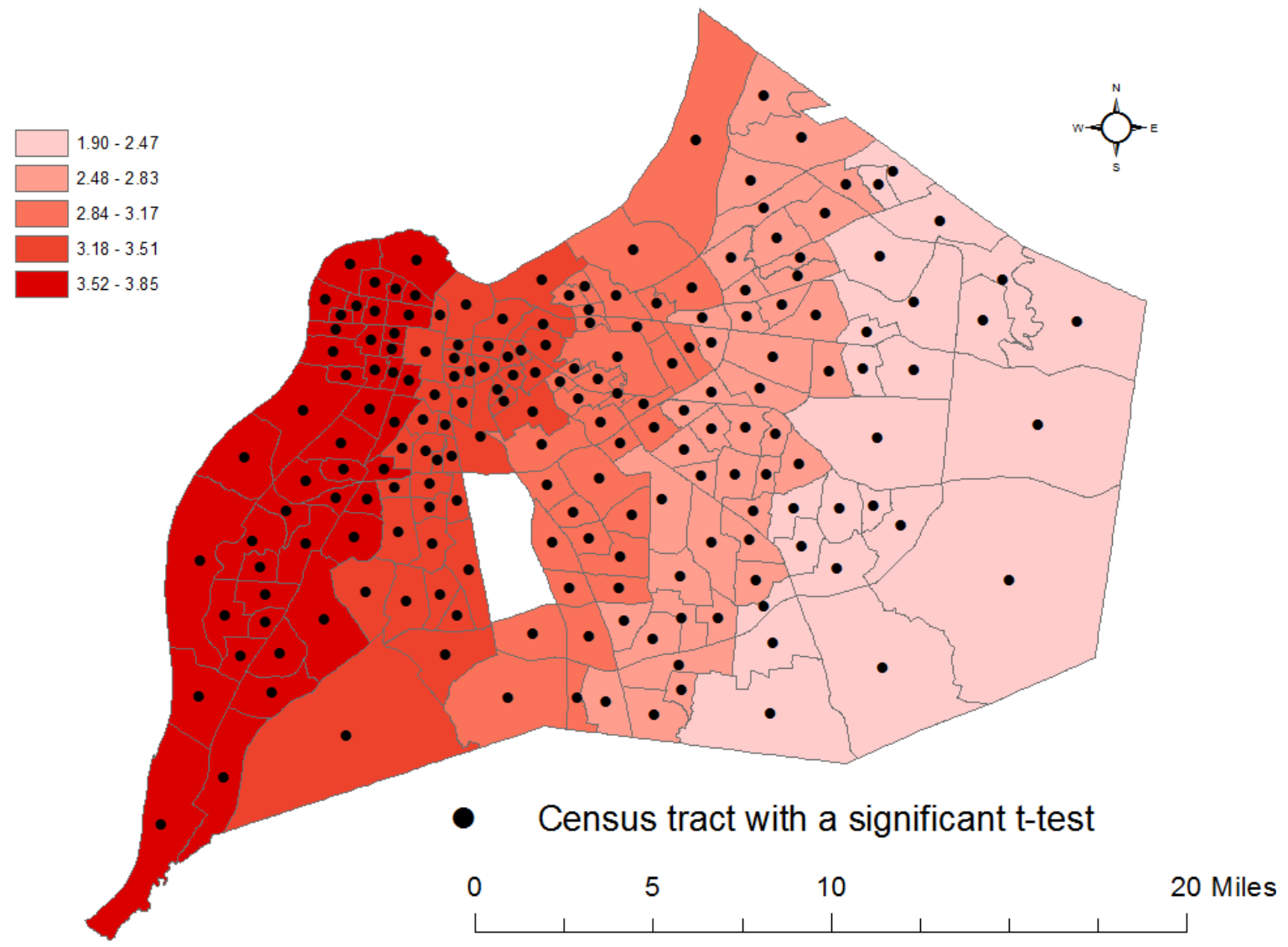

Figure 5. Local coefficients for urban amenities in 2016 and multiyear average robbery rates from 2010 to 2016.

Figure 5 demonstrates that the contemporary quality of a neighborhood has a statistically significant relationship with the multiyear average of robberies for all census tracts in Louisville, KY. The distribution coffee shops, breweries, distilleries, and wineries does have a significant relationship but the East End has much lower coefficients. There are less indicators in the East End in comparison to the CBD and surrounding neighborhoods. The positive relationship is occurring across the study area but the indicators have a larger impact on the high rate of robberies in the CBD and surrounding neighborhoods. 
The higher coefficients shown in figure 5 are concentrated west of the airport. These areas have many more robberies per year than the GWR model would predict. Most of these are not prime for gentrification as there are not diverse enough. The light blue areas fit within the distribution of the model. The Portland census tract stand to the North West of the CBD and two census tracts directly to the East demonstrate the likelihood of gentrification. As I mentioned, the alternative gentrification indicator has a strong positive relationship with multiyear average robbery rates. In contrast, the change in alternative gentrification indicators from 2010-2016 has a significant negative relationship with multiyear average robbery rates in 98 census tracts. All 98-census tracts are located in the West and South West, suggesting that the location of an alternative gentrification indicator in these tracts would decrease robberies. Figure 6 confirms my hypothesis that gentrification as measured by the alternative gentrification indicators decreased robberies from 2010 to 2016. 


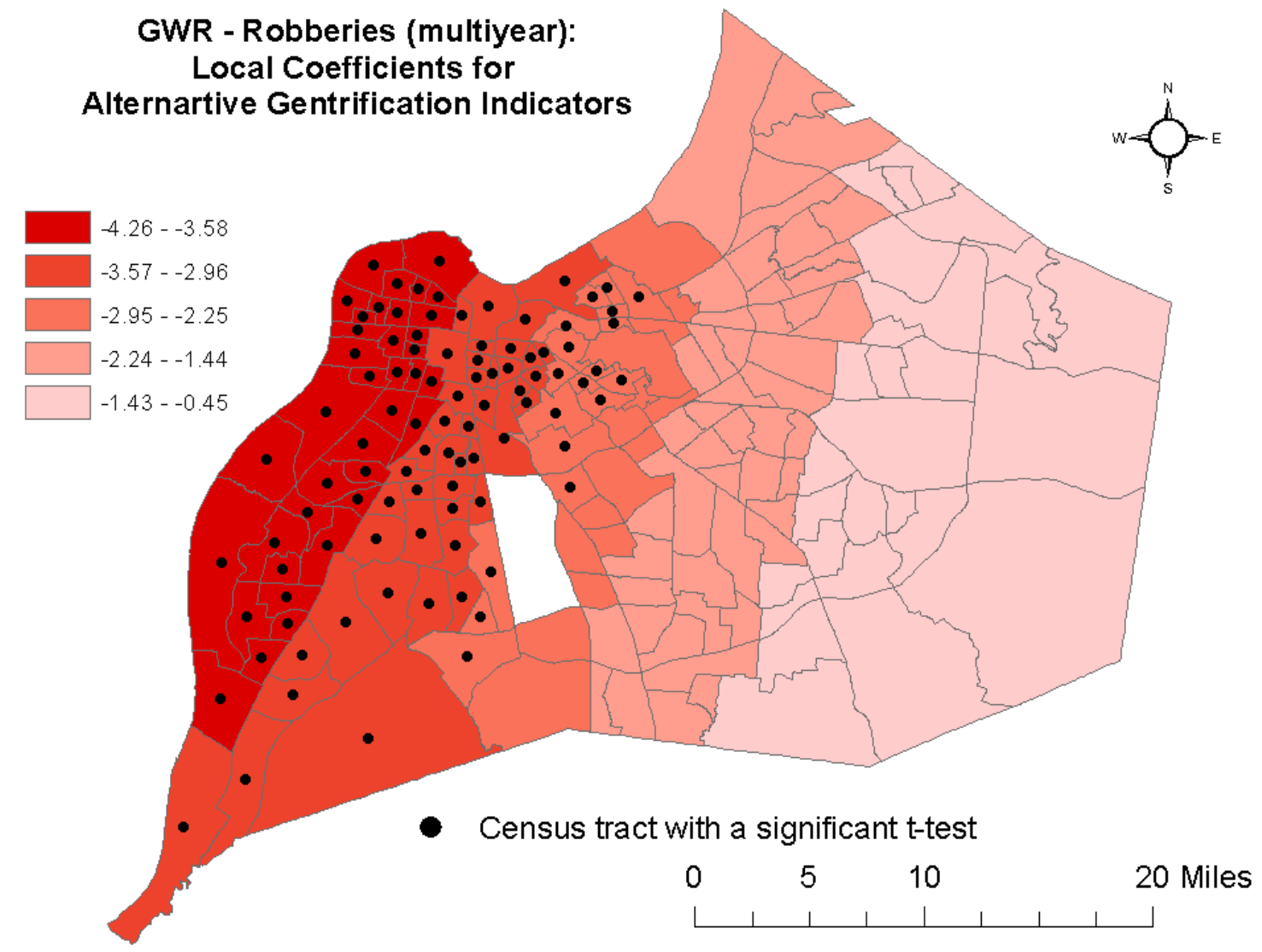

Figure 6. Local coefficients for alternative gentrification indicator from 2010 to 2016 and multiyear average robbery rates from 2010 to 2016.

\section{Homicides: GWR}

The following table 6 demonstrates the minimum, median, and maximum coefficients for independent variables for all 190 census tracts analyzed for their relationship with multiyear average homicide rates. The GWR results produce a coefficient and standard error for each individual census tract. A T-test was calculated in ArcGIS and found no significance for the second hypothesis, because neither the alternative gentrification indicators nor the change in the total count of alternative gentrification indicators form 2010 to 2016 had significant median t-test scores. This 
means that the model is not confident that coffee shops, breweries, distilleries, and wineries do not have a significant relationship with the spatial distribution of homicides in Louisville, KY from 2010 to 2016. The change over time variable displays a negative coefficient's for the minimum, median, and maximum, suggesting a certain negative relationship with homicide rates, but the localized GWR model cannot predict this with enough significance.

The median t-scores were significant for the percentage of residents in poverty $(+0.009)$, the percentage of minorities $(+0.007)$, the percentage of unemployment $(+0.02)$, the percentage of vacancies $(+0.02)$ in a neighborhoods $(+0.02)$, and the percentage of residential mobility (-0.9) as measured by people moving within a year. These are included in table 6. An unintended finding may suggests that census tracts with high residential ability are linked to less homicide rates. This may be something that future studies can focus on as the conventional wisdom suggests that areas with a higher percentage of renters would have higher homicide rates. Regardless, there is a lack of any evidence that the relationship between the alternative gentrification indicators have any impact on the occurrences of homicides from 2010 to 2016. 
Table 6. Results of GWR analysis for homicides (multiyear average) from 2010 to 2016.

\begin{tabular}{|c|c|c|c|}
\hline \multirow{2}{*}{ Independent Variable } & \multicolumn{3}{|l|}{ Coefficient } \\
\hline & Min & Med & Max \\
\hline Intercept & -0.54 & $-0.38^{*}$ & -0.2 \\
\hline $\begin{array}{l}\text { Urban Amenities (e.g. Coffee shops, breweries, distilleries, \& } \\
\text { wineries) }\end{array}$ & 0.02 & 0.03 & 0.03 \\
\hline Alternative Gentrification Indicators from 2010 to 2016 & -0.09 & -0.06 & -0.03 \\
\hline Education Attainment (Bachelors or higher 25 and over) & 0.0002 & 0.002 & 0.003 \\
\hline Median Household Income (US\$1000) & 0.001 & 0.002 & 0.004 \\
\hline$\%$ Poverty & 0.007 & $0.009 *$ & 0.01 \\
\hline$\%$ Unemployment & 0.01 & $0.02^{*}$ & 0.03 \\
\hline$\%$ Vacancy & 0.007 & $0.02 *$ & 0.02 \\
\hline$\%$ of Commercial Land Use & -0.007 & -0.006 & -0.006 \\
\hline$\%$ of Multi-Family Land Use & 0.002 & 0.006 & 0.01 \\
\hline Residential Mobility & -1.13 & $-0.9 *$ & -0.61 \\
\hline$\%$ of minorities (Non-White) & 0.006 & $0.007^{*}$ & 0.007 \\
\hline Local $R^{\wedge} 2$ & 0.57 & 0.66 & 0.72 \\
\hline Akaike's Informtion Criterion (AIC) & 93.23 & & \\
\hline$R^{\wedge} 2$ & 0.69 & & \\
\hline Adjusted R^2 & 0.65 & & \\
\hline
\end{tabular}

The GWR model displays a better fit in comparison to the OLS model, as the AIC value lowered from to 94.54 to 93.23 . The significant median t-scores were significant for the percentage of residents in poverty $(+0.009)$, the percentage of minorities $(+0.007)$, the percentage of unemployment $(+0.02)$, the percentage of vacancies $(+0.02)$ in a neighborhoods (+0.02), and the percentage of residential mobility (-0.9) as measured by people moving within a year. These are included in table 6 . An unintended finding may suggests that census tracts with high residential ability are linked to less homicide rates. This may be something that future studies can focus on as the conventional wisdom suggests that areas with a higher percentage of renters would have higher homicide rates. Regardless, there is a lack of any evidence that the relationship between the alternative 
gentrification indicators have any impact on the occurrences of homicides from 2010 to 2016. Figure 7 shows census tracts with a significant local coefficients for residential mobility. 


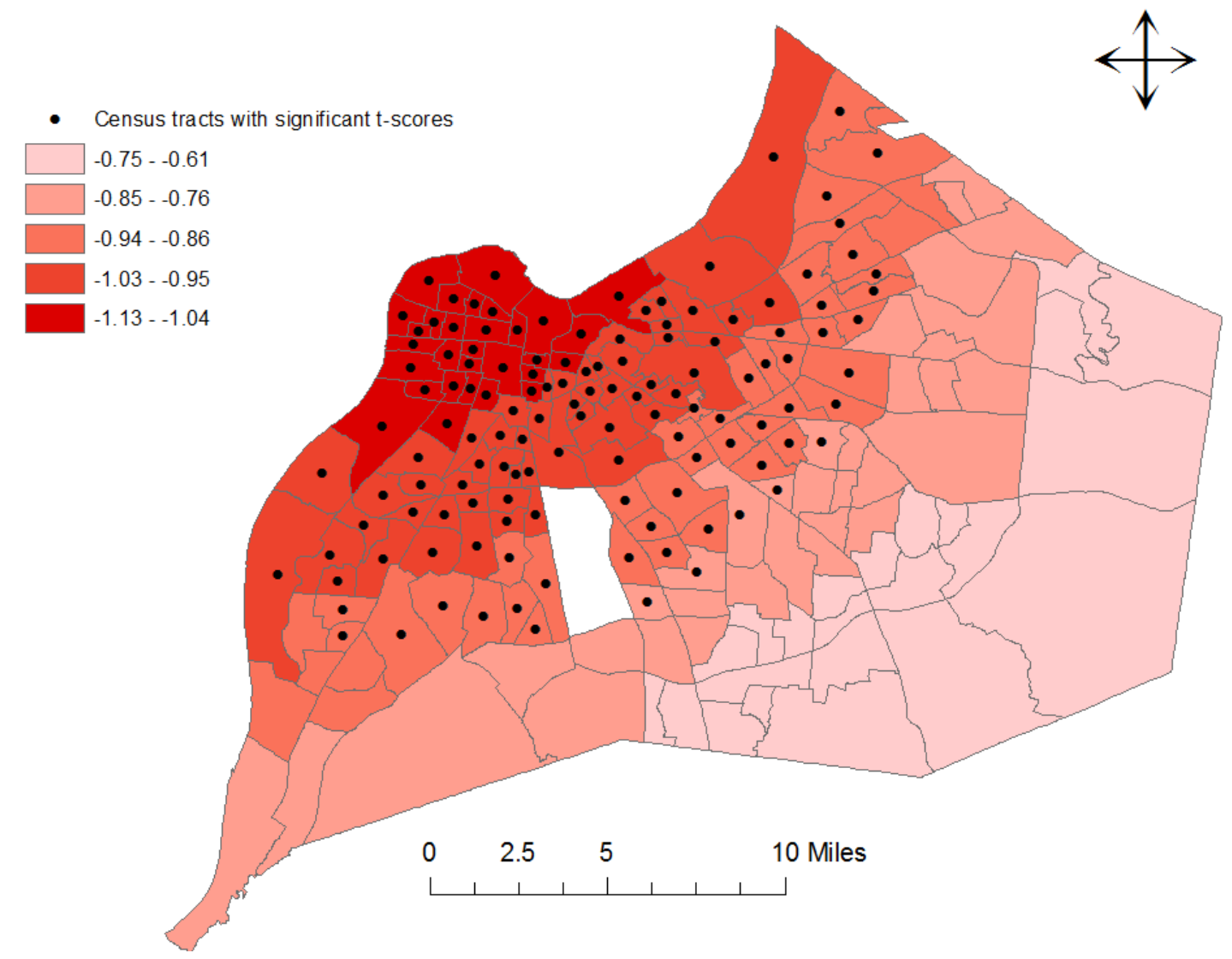

Figure 7. Local coefficients for residential mobility from 2010 to 2016 and the multiyear average for robbery from 2010 to 2016. 
Table 7. Comparison of Moran's-I results for all for models

\begin{tabular}{|l|c|c|c|}
\hline Model & Moran Index & z score & p-value \\
\hline OLS - Robberries (multiyear average) & 0.09 & 2.32 & $0.02^{* *}$ \\
\hline GWR - Robberies (multiyear average) & 0.07 & 1.84 & $0.06^{*}$ \\
\hline OLS - Homicdes (multiyear average) & 0.02 & 0.74 & 0.45 \\
\hline GWR - Homicides (multiyear average) & 0.001 & 0.17 & 0.86 \\
\hline * significant at the 90\% level; **95\% level & & \\
\hline
\end{tabular}

\section{Moran's-I}

The Moran's-I was conducted for the two OLS models and the two GWR models to check for autocorrelation. Table 7 shows the comparison of the Moran's index, Zscore, and probability value.

Table 7 confirms that Moran's-I from the OLS to a GWR analysis is much more accurate as it takes into account autocorrelation. This is important as it takes into account the spatial distribution of the data, as three are many census tracts that did not have coffee shops, breweries, distilleries, and wineries in both 2010 and in 2016. 


\section{CONCLUSION AND DISCUSSION}

The results provided a descriptive statistics of the current landscape in regards to gentrification and violent crimes. This allowed me to identify census tracts that are associated with neighborhoods like Portland, Phoenix Hill, and Butchertown that have experienced drastic changes amongst the built environment and social and demographic structure. These areas had a high percentage of whites in comparison to neighboring census tracts that have a higher concentration of minorities. These neighborhoods have seen an increase in coffee shops, breweries, and distilleries for the most part but an urban winery has located in the East Russel Neighborhood. The OLS model for both homicide and robberies were very capable with high R2values. The OLS model for multiyear average robbery rates found a significant relationship with alternative gentrification indicators. The lack of localization and taken into account rule of geography were confirmed by both models displaying heteroscedasticity, suggesting further spatial analysis. The GWR models for both robberies and homicides improved their overall performance as the AIC increased amongst both. The GWR analysis found that there is a significant positive relationship between alternative gentrification indicators and multiyear average robbery rates from 2010 to 2016.

This thesis has offered an additional approach to measuring gentrification to build upon the previous literature. These measurements included several types of urban amenity businesses including coffee shops, breweries, distilleries, and wineries. The use of coffee chops as an indicator of gentrification has been analyzed by Papachristos et al. 
(2011). This research acknowledges that there are other commercial activities that are associated with gentrification, as breweries and brew pubs have been analyzed by social scientists, but the emergences of these features amongst the urban landscape is undeniable. In Louisville, KY, the emergence of distilleries is well noted by the media and the distilling industry. Likewise, the urban winery movement is well noted by the wining industry and has been associated with gentrification. The identification of these urban amenity locations provides a contemporary understanding of the distribution of Louisville's population. The alternative gentrification indicators shows a significant relationship with multiyear average robbery rates for both the OLS and GWR models. The impact of robbery count is greater in areas of poverty. The GWR model has a higher degree of confidence in census tracts in the eastern portion of Louisville. In regards to homicides, there was a lack of any significant relationship between the alternative gentrification indicators and multiyear average homicide rates. These results preclude the concluding discussion.

Future analysis could improve in this study by conducting the GWR at the block group level. This would provide a better understanding of the processes occurring within the neighborhoods. Unfortunately, the ACS 5 year dataset is not complete for block groups, but the location of urban amenities and the computed alternative gentrification indicator can easily be analyzed at a finer scale. In addition, limiting the study area to urban areas only would provide a clearer understanding. In Louisville's case, a similar analysis in the future should focus on block groups that fall inside of the Watterson Expressway. This would provide more accuracy. 
The relationship between violent crimes and the process of gentrification can be measured and analyzed in a variety of ways. The methodologies chosen for this study are empirical but use data derived from both quantitative and qualitative findings. It is important to bring up the difference between analyzing crime data by counts versus rates, this study used the Urban Amenities as an indication of areas that are highly populated. An analyst that takes into account the distribution of population can be used by analyzing crime rates as opposed to multiyear averages. Future regression analysis should incorporate a comparison between counts and rates in regards to violent crime.

The addition of breweries, distilleries, and wineries to coffee shops, has proven to simply add to commercial activities that can pin point market and demographic transitions. They add to the literature as an attempt to add additional variable to the intermittent variables used by scientists. The literature sought for cities with less segregation to be analyzed for relationships between coffee shops and crime (Papachristos et al. 2011). Coffee Shops are indeed a hallmark of gentrification, and the addition of microbreweries, artesian distilleries, and urban that offer tourist attractions and tap rooms are just as prevalent in the inner city. Their presence in the urban fabric has increased and being coupled with coffee shops provides these thesis alternative indicators for measuring gentrification. 


\section{REFERENCES}

Aikman, M. 2014. Gentrification's effect on crime rates. Urban Economics.

Akers, R. 1990. Rational choice, deterrence, and social learning theory in criminology: the path not taken. Journal of Criminal Law and Criminology 81 (3): 653-676.

Anderson, E. 1990. Streetwise: race, class, and change in the urban community. Chicago, IL: The University of Chicago Press.

Anselin, L., J. Cohen, D. Cook, W. Gorr, and G. Tita. 2000. Spatial analysis of crime. Measurement and Analysis of Crime and Justice 4: 213-262.

Atkinson, R. and G. Bridge, eds. 2004. Gentrification in a global context. Routledge.

Barton, M. 2014. Gentrification and violent crime in New York City. Crime and Delinquency 62(9):1-23.

Barton, M. and C. Gruner. 2016. A theoretical explanation of the influence of gentrification on neighborhood crime. Deviant Behavior 37(1): 30-46.

Bostic, R. and R. Martin. 2003. Black home-owners as a gentrifying force? Neighborhood dynamics in the context of minority home-ownership. Urban Studies 40(12) 2427-2449.

Bourbon and food work group report. 2014. Louisville Mayor's Office. Available at https://louisvilleky.gov/sites/default/files/mayors_office/bourbonreport5.pdf (last accessed 24 April 2017). 
Bourbon Country. Urban bourbon experience. Available at http://gotolouisville.s3.amazonaws.com/CMS/5444/urban_bourbon_experience.p df (last accessed 24 April 2017)

Brehon, D. 2007. Essays on the economics and econometrics of urban crime and house price prediction. Unpublished PhD diss. Columbia University, New York, NY.

Cohen, L., and M. Felson. 1979. Social change and crime rate trends: a routine activities approach. American Sociology Review 44(4): 558-608.

Cortright, J. 2015. In defense of gentrification. The Atlantic. Available at http://www.theatlantic.com/business/archive/2015/10/in-defense-ofgentrification/413425/ (last accessed 24 April 2017)

Covington, J., and R. Taylor. 1989. Gentrification and crime: robbery and larceny changes in appreciating Baltimore neighborhoods during the 1970s. Urban Affairs Quarterly 25(1): 142-172.

Dastrup, S., I. Ellen, A. Jefferson, M. Weselcouch, D. Schwartz, and K. Cuenca. 2015. The effects of neighborhood change on New York City housing authority residents. NYC Center for Economic Opportunity. New York, NY. Available at http://www.nyc.gov/html/ceo/downloads/pdf/nns_15.pdf (last accessed 24 April 2017)

Davidson, J. 2014. Is Gentrification All Bad? New York News and Politics. Available at http://nymag.com/news/features/gentrification-2014-2/ (last accessed 16 March 2017)

Ding, L., J. Hwang. and E. Divringi. 2016. Gentrification and residential mobility in Philadelphia. The Federal Reserve Bank of Philadelphia. Available at 
https://www.philadelphiafed.org/-/media/community-

development/publications/discussion-papers/discussion-paper_gentrification-andresidential-mobility.pdf (last accessed 24 April 2017)

Florida, R. 2002. The rise of the creative class: and how it's transforming work, leisure, community and everyday life. New York, NY: Basic Books.

Form, W. and J. Dubrow. 2008. Ecology of denominational fundamentalism in a metropolis. City and Community 7(2): 141-162.

Freeman, L., and F. Barconi. 2004. Gentrification and displacement in New York City in the 1990s. Journal of the American Planning Association 71(3) 39-52.

Freeman, L. 2005. Displacement or succession? residential mobility in gentrifying neighborhoods. Urban Affairs Review 40(4): 463-491.

Freeman, L. 2006. There goes the hood: views of gentrification from the ground up. Philadelphia, PA: Temple University Press.

Freeman, L., A. Cassola, and T. Cai. 2016. Displacement and gentrification in England and Wales: a quasi-experimental approach. Urban Studies 35(13) 2797-2814.

Garland, D. and R. Sparks. 2000. Criminology, social theory and the challenge of our times. British Journal of Criminology 40: 189-204.

Gibbons, D. 1979. The criminological enterprise: theories and perspectives. Englewood Cliffs, NJ: Prentice Hall.

Glaser, D. 1971. Social Deviance. Chicago, IL: Markham.

Gordinier, J. 2016. South bronx gets high-end coffee; is gentrification next? The New York Time. Available at https://www.nytimes.com/2016/06/01/dining/coffeeshops-south-bronx.html?_r=0 (last accessed 24 April 2017) 
Hagan, J. 1973. Labeling and deviance: a case study in the sociology of the interesting. Social Problems 20: 447-458.

Hammel, D., and E. Wyly. 1996. A model for identifying gentrified areas. Urban Geography 17(3): 248-68.

Jasper, I. 2016. Gentrification in Washington DC analysis and policy recommendations. Master's thesis, College of Architecture, Art, and Planning, Cornell University, Ithica, NY.

Kennedy, M. and P. Leonard. 2001. Dealing with neighborhood change: a primer on gentrification and policy changes. The Brookings Institution Center on Urban and Metropolitan. Available at http://www.policylink.org/sites/default/files/DealingWithGentrification_final.pdf (last accessed 24 April 2017)

Kentucky Distillers' Association. 2014. "Bourbon 2020” request for proposals to update five-year strategic plan. Available at http://kybourbon.com/wpcontent/uploads/2015/01/KDA-Bourbon-2020-RFP.pdf (last accessed 24 April 2017)

Kornstein, B. and J. Luckett. 2013. The economic and fiscal Impacts of the distilling industry in Kentucky. University of Louisville Urban Studies Institute. Available at https://louisville.edu/upa/research-centers-1/2014KDAReport2014.pdf (last accessed 24 April 2017)

Kreager, D., C. Lyons, and Z, Hays. 2007. Condos, coffee shops, and crime: gentrification and Seattle crime trends. Presented at the 2007 American Society of Criminology Annual Conference. Atlanta, GA. 
Kubrin, C., and R. Weitzer. 2003. New directions in social disorganization theory.

Journal of Research in Crime and Delinquency 40(4) 374-402.

Lee, M. and K. Goulias. 1996. Accessibility indicators for transportation planning using gis. Available at http://www.geog.ucsb.edu/geotrans/publications/Lee\%20and\%20Goulias\%20acce ssibility\%20to\%20shopping\%20TRB\%20paper\%201996.pdf (last accessed 24 April 2017)

Lee, Y. 2010. Gentrification and crime: identification using the 1994 Northridge earthquake in Los Angeles. Journal of Urban Affairs 32(5): 549-577.

Ley, D. 2003. Artists, aestheticisation and the field of gentrification. Urban Studies 40 (12): 2527-2544.

Mathews, V. 2014. Intoxifying gentrification: brew-pubs and the geography of postindustrial heritage. Urban Geography 35(3).

McCormick, E. 1999. Using a GIS to enhance the value of travel diaries. ITE Journal 69(1): 38-39.

McDonald, Scott C. 1986. Does gentrification affect crime rates? Communities and Crime 8: 160-203.

McKinsey, J. 2008. Making wine in the city: the business and regulation of the urban winery. Wine Business Monthly. Available at https://www.winebusiness.com/wbm/?go=getArticleSignIn\&dataId=54607 (last accessed 24 April 2017)

Meinen, T. 2014. Neighborhood disorder, crime and the broken windows theory: an examination into the relationship between neighborhood disorder and crime in the 
city districts of Rotterdam. Master's Thesis, University of Twente, Enschede. Available at http://essay.utwente.nl/66424/1/Meinen_MA_MB.pdf (last accessed 24 April 2017)

Miller J., C. Schreck, and R. Tewksbury. 2006. Criminology theory: a brief introduction. Boston, MA: Pearson/Allyn and Bacon.

Northeast University College of Social Scientists and Humanities. 2016. Gentrification and the caffeine curse. Available at https://www.northeastern.edu/cssh/policyschool/2016/05/gentrification-caffeinecurse/ (last accessed 24 April 2017)

Papachristos, A., C. Smith, M. Chris, M. Scherer, and M. Fugiero. 2011. More Coffee, Less Crime? The Relationship between Gentrification and Neighborhood Crime rates in Chicago, 1991 to 2005. City and Community 10(3):215-240.

Patterson, T. 2007. Urban economics: a city winery can make 3,000 cases with a $\$ 100,000$ investment. Wine and Vines, Available at https://www.winesandvines.com/template.cfm?section=features\&content=51146 (last accessed 24 April 2017)

Pullman, M., J. Greene, D. Liebmann, N. Ho, and X. Pedisich. 2015. Hopworks urban brewery: a case of sustainable beer. Portland State University. Portland, OR. Available at http://pdxscholar.library.pdx.edu/cgi/viewcontent.cgi?article=1029\&context=busa dmin_fac (last accessed 24 2017)

Roncek, D. and Maier, P. Bars, blocks and Crime revisited: linking the theory of routine activities to the empiricism of hot spots. Criminology 29: 725-753. 
Sampson, R. and Groves, W. 1989. Community structure and crime: testing social disorganization theory. American Journal of Sociology 94: 774-802.

Sampson, R., S. Raudenbush, and F. Earls. 1997. Neighborhoods and violent crime: a multilevel study of collective efficacy. Science 277: 918-24.

Schaffer, R. and N. Smith. 1986. The gentrification of Harlem? Annals of the Association of American Geographer 76(3): 347-365.

Sharkey, P., A. Schwartz, I. Ellen, and J. Lacoe. 2014. High stakes in the classroom, high stakes on the street: the effects of community violence on students' standardized test performance. Sociological Science 1: 199-220.

Shelden, R. 2004. Accessing: broken windows: a brief critique. Center on juvenile and criminal justice. Available at http://www.cjcj.org/uploads/cjcj/documents/broken.pdf (last accessed 26 March 2017)

Sherman, L., P. Gartin, and M. Bueger. 1989. Hot spots of predatory crime: routine activities and criminology of place. Criminology 27: 27-55.

Sheppard, S. 2015. Why is gentrification a problem? Center for creative community Development. Williams College, Williamstown, MA.

Skogan, W. 1990. Disorder and decline: crime and the spiral decay in American neighborhoods. New York, NY: The Free Press.

Smith, Neil. 1996. The new urban frontier: gentrification and the revanchist city. New York City, NY: Routledge.

Tobler, W. 1979. Cellular geography. Philosophy of Geography 20: 379-386. 
Van Wilsem, J., K. Wittebrood, and N.De Graaf. 2006. Socioeconomic dynamics of neighborhoods and the risk of crime victimization: a multilevel study of improving, declining, and stable areas in the Netherlands. Social Problems 53(2): $226-247$.

Vine, M., D. Degnan, and C. Hanchette. 1997. Geographic information systems: their use in environmental epidemiological research. Environmental Health Perspectives 105(6): 599-605.

VornDick, W. 2014. The global urban winery crush: model, forecast and prospect. American Association of Wine Economists. Available at https://www.wineeconomics.org/aawe/wp-content/uploads/2014/05/AAWE_WP156.pdf (last accessed 24 April 2017)

Ward, M., and K. Gleditsch, 2007. An introduction to spatial regression models in social sciences. Available at http://docplayer.net/10971536-An-introduction-to-spatialregression-models-in-the-social-sciences.html. (last accessed 25 April 2017)

Wilson, J., and G. Kelling. 1982. The police and neighborhood safety: broken windows. Atlantic Monthly 249: 29-36.

Yu, S. 2009. Bus stops and crime: do bus stops increase crime opportunities in local neighborhoods? Master's thesis, Rutgers University, Newark, NJ.

Zhang, Haifeng, and Eric S. McCord. "A spatial analysis of the impact of housing foreclosures on residential burglary." Applied Geography 54 (2014): 27-34.

Zuk, M., A. Bierbaum, K. Gorska, A. Loukaitou-Sideris, and T. Thomas. 2015. Gentrification, displacement and the role of public investment: a literature review. Federal Reserve Bank of San Francisco. Available at 
http://www.frbsf.org/community-development/publications/working-

papers/2015/august/gentrification-displacement-role-of-public-investment/ (last accessed 25 April 2017)

Zukin, S. 2008. Consuming authenticity: from outposts of difference to means of exclusion. Cultural Studies 22(5): 724-748.

Zukin, S. 1987. Gentrification: culture and capital in the urban core. Annual Review of Sociology 13: 129-14. 


\section{CURRICULUM VITAE}

NAME: George Alan Noonan

ADDRESS: Department of Geography and Geosciences University of Louisville

Louisville, KY 40292

DOB: $\quad$ Louisville, Kentucky - December 2, 1986

EDUCATION

\& TRAINING: $\quad$ B.S. Geography and Geosciences

University of Louisville

2013-2015 